\title{
The cross-country determinants of potential and actual migration*
}

\author{
Frédéric Docquier ${ }^{a}$, Giovanni Peri ${ }^{b}$, Ilse Ruyssen ${ }^{c}$ \\ ${ }^{a}$ FNRS and IRES, UCLouvain $\quad{ }^{b}$ University of California, Davis \\ $d$ SHERPPA, Ghent University, and IRES, UCLouvain
}

August 4, 2014

\begin{abstract}
In this study we use cross-country bilateral data to quantify a twostep process of international migration and its aggregate determinants. We first analyze which country-specific factors affect the probability that individuals join the pool of potential (aspiring) migrants. Then we consider the bilateral and destination country factors that affect the frequency at which potential migrants turn into actual migrants. Using information on potential migrants from World Gallup surveys and on actual migrants from national censuses for 138 origin countries and 30 major destinations between 2000 and 2010, we analyze economic, policy, cultural and network determinants of each step. We find that the size of the network of previous migrants and the average income per person at destination are crucial determinants of the size of the pool of potential migrants. Economic growth in the destination country, on the other hand, is the main economic generator of migration opportunities for a given pool of potential migrants. We also find that college educated exhibit greater actual emigration rates mainly
\end{abstract}

*We thank the editors and three referees for their helpful remarks and suggestions. We acknowledge financial support from the ARC convention on "Geographical Mobility of Factors" (convention 09/14-019). We also gratefully thank Robert Manchin and the Gallupinitiated Institute for Advanced Behavioural Studies for allowing us access to the data for research purposes. Correspondence: Frédéric Docquier (frederic.docquier@uclouvain.be), Giovanni Peri (gperi@ucdavis.edu) and Ilse Ruyssen (ilse.ruyssen@uclouvain.be). 
because of better chances in realizing their immigration potentials, rather than because of higher willingness to migrate.

Keywords: Potential Migrants, Migration Aspirations, Migration Opportunities, College Educated, Migration Policies, Economic factors.

Article Classification: Research paper

\section{INTRODUCTION}

Migrating from a country of origin to a country of destination involves several steps, not all of them observable and measurable (Paul, 2011). This paper relates to the existing literature by considering the migration process as comprised of two main steps. We first analyze the macro-determinants of the aggregate probabilities of becoming potential migrants (first-step) and then we look at the factors determining what fraction of potential become actual (second-step) migrants. A tradition in the migration literature identifies a clear first step in the decision of looking for migration opportunities. "Aspiring" migrants are those who express an intention/desire to emigrate (Becerra, 2012; Carling, 2002; Creighton, 2013, van Dalen et al., 2005a, van Dalen et al. 2005b, Jónsson, 2008). Several studies have used survey questions to elicit this information and have thoroughly analyzed specific cases, often focused on one country of origin or one migration corridor, such as Mexico-US. These studies have been focused on uncovering detailed motivations of potential migrants and on individual level analysis, but are hard to compare with each other or across countries and to generalize into quantifiable tendencies.

From an economist's perspective, deciding to be in the pool of potential migrants is explained as a rational decision. Individuals evaluate how desirable it would be to migrate to a foreign country relative to staying in the country of origin. An implicit comparison of the utility (benefits minus costs) of staying with the utility of migrating to different potential countries is made by individuals. "Potential" migrants are those who state a preference for migrating (arguably because perceived benefits of migrating are larger than perceived costs). Those benefits and costs depend on the presence of family members abroad, on individual characteristics and on economic and social conditions, among other things. Hence, a large part of the sociological litera-

ture, relating those factors to the intention of migrating (both by individuals 
and families), can be interpreted in this framework (e.g. Papapanagos and Sanfey, 2001; Wood et al., 2010; Yang, 2000).

The second step of the migration process takes place when some searchers in the pool of potential migrants find opportunities to migrate - such as a job offer, a temporary visa, a study opportunity or a family permit and migrate. The interactions between potential migrants and migration opportunities determine the flow of actual migrants (Carling, 2002). From an economic perspective it can be considered as somewhat similar to a matching process: Heterogeneous individuals who are willing to migrate find - through a slow and costly process - potential migration opportunities. Pissarides (2000) popularized the use of search and matching in labor market studies. Some of the underlying features of those models can be used in the analysis of how potential migrants (searchers) and migration opportunities are matched and produce the flow of actual migrants.

In the present study we implement a simple two-stage empirical analysis to illustrate the role of aggregate determinants of migration flows. First, we analyze empirically what country-specific and bilateral factors determine the size (and composition between education groups) of the pool of potential migrants. The latter is defined as those who have revealed being willing to migrate by positively answering the question "Ideally, if you had the opportunity, would you like to move permanently or temporarily to another country, or would you prefer to continue living in this country?". Most of them have, then, indicated a preferred country in the follow-up question "To which country would you like to move?". In the second step we analyze how these potential migrants combine with factors determining migration opportunities and generate actual migration flows.

The answers to the questions described above were obtained from representative Gallup polls (described in detail in Gallup, 2012) and available for 138 countries - representing 97 percent of the world population - between 2007 and 2013. After organizing, cleaning and aggregating these data by origin-destination pairs, we merged them with data on actual bilateral net migration flows for the 2000-2010 period from 138 countries to 30 major migrant-receiving countries. Bilateral net migrations are measured as the difference in the stock of migrants from an origin to a specific destination between 2000 and 2010. Hence, they are good estimates of the long-term flows of permanent migrants. Dividing by native population in the country of origin we construct net migration rates and potential migration rates between country pairs over the 2000-2010 decade. With these bilateral data 
we analyze in a simple econometric framework how the pool of potential migrants and migration opportunities (stemming among others from economic growth, policies in the receiving country, the presence of networks) determine the net migration rates. In doing so we learn (i) which factors affect migration by changing the share of potential migrants in the population and (ii) which factors affect the actual migration rate, given the pool of potential migrants.

Throughout our analysis, we distinguish between individuals with at least some college education (that we call college-educated) and those without (sometimes called "less educated" or non-college educated) ${ }^{[1]}$. Their increasingly different labor market performance in most developed countries (Autor et al., 2008; Goldin and Katz, 2008; Moretti, 2012), and - even more importantly - their different degree of national and international mobility (Grogger and Hanson, 2011; Artuç et al., forthcoming), call for a separate analysis to better understand their differences. Are college educated individuals more mobile because they are more likely to be potential migrants in response to perceived economic opportunities? Or are they more mobile because within the pool of potential migrants, they have a greater probability of finding opportunities? As most receiving countries' immigration policies, either directly or covertly, favor highly educated immigrants, differences in the rate of realization of migration opportunities between college educated and noncollege educated are likely to depend on immigration policies. Alternatively, college educated may be able to navigate through foreign labor markets more easily and acquire knowledge of more opportunities.

Several interesting results emerge from our analysis. First, supporting the cost-benefit model used as the basis of economic studies of migration, we find that the average income at destination and the presence of networks of previous migrants are robust and quantitatively significant determinants of potential migration rates. Interestingly college educated and non-college educated respond to destination income and networks in a broadly similar way when it comes to willingness to migrate. On average, the less educated are only somewhat less likely to be willing to migrate and their willingness to migrate responds to economic incentives with similar elasticities as college educated. Yet, college educated have a three to four times larger probability of actually migrating, once in the pool of potential migrants. This is the main factor determining skill-biased emigration. Third, growth in gross domestic product (GDP) per capita in the receiving country is the only economic factor that we find positively correlated with migration rates once we 
control for the pool of potential migrants, and such correlation is stronger for non-college educated. Fourth, policies allowing free mobility of labor across borders (such as within the European Union), which are the closest to having open borders, had a small (and sometimes statistically insignificant) effect in translating potential into actual migrants among non-college educated. They had no effect on the mobility of college educated in 2000-2010. Similarly the presence of visa-waiver agreement between countries has a positive but small correlation with actual migration flows of the less educated, for given potential. One has to keep in mind, however, that free migration policies only exist between rather similar countries within Europe. Likewise, visa waiving agreements exist between countries with similar levels of development and democracy, mainly the rich Western countries (Neumayer, 2006). Finally, we find that economic growth in the destination countries had a proportionally stronger effect on migration opportunities from sending countries where the pool of potential migrants to that destination was larger. Networks in the destination country, income differentials and geographical and cultural proximity had only a minor impact on migration rates once we control for the pool of potential searchers.

The rest of the paper is organized as follows. First, we review the existing literature on the determinants of migration, focusing on the empirical aggregate approach we use that derives from the economics literature. In the following section, we present the data on potential and on actual migrants and show some descriptive statistics and general trends. Subsequently, we provide the framework for the empirical analysis. In the empirical section, we first estimate the impact of economic characteristics, policy variables and network size on the pool of searchers, among college and non-college educated. Subsequently, we analyze how the pool of potential migrants and receiving-country opportunities determine actual migration rates of college and non-college educated. We end with a brief summary and some conclusions.

\section{LITERATURE REVIEW}

The classical way economists look at migration has been by founding the decision to migrate in an individual cost-benefit analysis (utility maximization). By aggregating heterogeneous individuals this framework has allowed scholars to analyze the determinants of aggregate migration flows and the 
selection of migrants (along the skill dimension). Examples of this approach can be found in Borjas (1987), Clark et al. (2007), Grogger and Hanson (2011), Hatton (2005), Roy (1951) and Sjastaad (1962). In this paper, we use this aggregate empirical perspective based on an individual cost-benefit analysis. However we incorporate it in a two-step process by analyzing first the aspiration and then the realization of migration potentials in sequence. This approach draws inspiration from a framework that has long been applied in other social sciences. As mentioned in the introduction, several studies (e.g. Becerra, 2012; Carling, 2002; Creighton, 2013; Czaika, M. and Vothknecht, 2014; De Jong, 2000; Hagen-Zanker et al. 2009; van Dalen et al., 2005) have recognized the importance of analyzing the factors influencing the aspiration to migrate in specific countries and contexts. Some of these studies have explicitly taken a two-step approach, analyzing (i) aspirations and (ii) ability to migrate (Carling, 2002). Our analysis extends this approach by drawing upon additional economic theory and using a uniquely extensive dataset. Our two-step analysis is loosely based on utility maximization in the first step and "matching" of potential migrants and migration opportunities in the second.

Empirically, the specifications we use to analyze the "first step" are similar to the bilateral gravity-like regressions grounded on theoretical microfoundations and used in several previous studies (e.g. Karemera et al., 2000; Hatton and Williamson, 2005; Clark et al., 2007; Bahna, 2008; Hooghe et al., 2008; Pedersen et al., 2008; Mayda, 2010; Ruyssen et al., 2014). Several recent papers have refined the economic analysis of the determinants of migration, framing the empirical estimates within a more rigorous multi-country choice, random utility maximization model derived from McFadden (1974). Grogger and Hanson (2011), Beine et al. (2011) and Ortega and Peri (2013), for instance, analyze bilateral migration as the result of a multinomial choice among alternative locations, driven by utility maximization determined by a comparison of costs and benefits. They relate the migrant/non-migrant ratios to economic and policy factors. Recently, Bertoli and Fernández-Huertas (2013) extended this framework to more general decision structures and implemented more complex, yet more general, econometric analyses. More generally, Beine et al. (forthcoming) discuss the methodological challenges that are implied by the use of bilateral data for the analysis of international migration. These papers are closely related to ours in that they also use aggregate bilateral cross-country data to identify determinants of migration flows. 
In the first step we analyze the role of several factors that previous researchers have found to be important in affecting costs and benefits of migration. First of all income and job availability at destination, but also geographical, cultural and institutional distance and social linkages (networks) between countries. Fawcett (1989), Bauer and Zimmerman (1997), Hooghe et al. (2008), Pedersen et al. (2008), Mayda (2010), Beine et al. (2011) and Ruyssen et al. (2014) are examples analyzing the impact of some of these factors directly on migration. Differently from these studies, however, we first focus on the impact of those factors on potential (rather than actual) migration.

The second part of our analysis looks at the process of combining potential migrants with factors that produce migration opportunities. In this respect, the combination of potential migrants and potential opportunities in receiving countries can be described in the context of a "matching" function (as in Pissarides and Petrongolo, 2001; Petrongolo and Pissarides, 2006; or Gregg and Petrongolo, 2005 among others) that summarizes the slow and uncertain process through which potential migrants realize migration opportunities. This is a somewhat new way of looking at the second stage of the migration process in which potential migrants become actual migrants. By including policy, cultural, geographical and other determinants of the likelihood of migration among potential migrants, we want to identify all factors (economic and not) that affect the probability that a potential migrant turns into an actual migrant.

There is a small but growing literature analyzing migration opportunities in a search and matching framework. Chassamboulli and Peri (2014), for instance, used such a framework to investigate the effect of the US immigration policy on illegal immigration from Mexico. Ortega (2000), on the other hand, theoretically showed that multiplicity of equilibria can arise from the interaction of searching firms' and migrants' optimizing behavior due to search and job creation externalities. Whereas those are search and matching models of migration for labor reasons, this paper uses the matching framework in a broader sense. In particular, we use bilateral data to statistically describe the process of matching potential migrants with "migration opportunities". It is worth noticing that we do not directly observe "migration opportunities" (namely the number of jobs, permits or visas available to foreigners) in receiving countries. We can identify, however, some receiving-country factors (such as productivity growth and policies) that could affect the availability of those opportunities and the probability of matching them with potential 
migrants.

As the Gallup data on willingness to migrate are new, the literature relying on these data to capture potential migration is very limited. There are several studies analyzing the willingness (aspiration) to migrate using country specific surveys-for instance in Mexico (Becerra, 2012; Becerra et al. 2010; Creighton, 2013), in Cape Verde (Carling, 2002), in North Africa (van Dalen 2005) and in China (Yang, 2000), just to cite a few. The fact that our database, on the other hand, covers all countries in the world makes it exceptional. A recent report by the International Migration Organization (Esipova et al., 2011) presents detailed descriptive statistics on the willingness to migrate across countries based on these data. A very recent working paper by Manchin et al. (2014), in addition, analyzes the importance of individual satisfaction on the desire to migrate using individual data from the same Gallup Poll, disregarding the bilateral dimension.

\section{DATA ON MIGRATION AND WILLINGNESS TO MIGRATE}

Our database includes 138 countries of origin for which data on both actual and desired emigration are available towards 30 major destination countries [2]. The set of destinations includes all major OECD countries as well as Persian Gulf countries, the Russian Federation and South Africa. According to the United Nations database, our set of destination countries accounts for 66.3 percent of the worldwide stock of international migrants in 2010 (and 63.4 percent of the stock in 2000). Throughout our analysis, we always separate college-educated individuals (denoted as $h$ ) who attended some tertiary education and less (or non-college-) educated individuals (denoted with $l$ ) who did not attend any tertiary education. These two groups are very different in terms of wage, job type and mobility. During the recent decades their economic differences, especially in developed countries, have grown (see Moretti, 2012, Autor et al., 2008). We compare statistics and findings for the two groups. Our set of 30 destination countries accounted, respectively, for 82.5 and 57.8 of the stock of highly and less educated adult migrants in the year 2000 .

We focus on bilateral migration flows over the period 2000-2010. The actual migration rate from country of origin $o$ to destination country $d$ is calculated as the net migration flow (obtained as the difference between the 2010 and the 2000 stocks of people born in $o$ residing in country $d$ ), nor- 
malized by the native non-migrant population of country $o$ in 2000. These bilateral rates are denoted by $m_{o, d}^{h}$ and $m_{o, d}^{l}$ for college and non-college educated, respectively. While net migration rates over 10 years imperfectly capture short-term gross migration ${ }^{[3]}$, they represent more closely the change in permanent migrants. Moreover net measures of migration, as they are derived from census data (rather than from registers of entry), are much more reliable and include non-documented migrants in several countries.

We then define the "desired" (though unrealized) migration rate from country $o$ to country $d$ as the share among native non-migrants in country $o$, interviewed by the Gallup Poll between 2007 and 2013, who said that they would be willing to migrate (permanently or temporarily) to country $d$ if they had an opportunity, but who are still in the country of origin. Whereas most respondents indicated a specific country of desired migration, some individuals only demonstrate a willingness to migrate but no specific desired destination. We considered all those who indicated a preference for migrating as "willing" and allocated those who did not express a country preference in proportion of the preferences expressed by those who did. ${ }^{4]}$ We denote these bilateral rates as $w_{o, d}^{h}$ and $w_{o, d}^{l}$ (for "willingness"), respectively for college and non-college educated. The population of reference, encompassing all people who could, in principle, migrate, is always the initial population of natives in country $o$ as of the year 2000, denoted by $N_{o}^{h}$ and $N_{o}^{l}$, respectively, for college and non-college educated. The rates $m$ and $w$ are both expressed relative to this initial population of natives in 2000. The sum of those two rates, therefore, gives the "potential" emigration rate. It combines those who emigrated (between 2000-2010) and those who are willing to migrate but were still in the country of origin by 2010. Hence, potential migration rates are denoted by $p_{o, d}^{h}=m_{o, d}^{h}+w_{o, d}^{h}$ and $p_{o, d}^{l}=m_{o, d}^{l}+w_{o, d}^{l}$. To capture some key characteristics of potential and actual migrants let us consider some summary statistics and aggregate features of migration rates from the origin and destination countries' perspectives.

\section{General overview}

Table 1 shows the values for emigration rates of college educated and the less educated (without college degree), averaging 138 countries of origin in the upper part of the table. In the second row we show the actual net emigration rate, and in the third row the "desired" emigration rate as defined above. In the first row, for comparison, we show the stock of emigrants relative 
to the native population as of 2000. The first two columns of the table show the values averaged across countries of origin, weighted by their native population. The percentages correspond to those in the aggregate native population. The third and fourth columns, on the other hand, show the simple average rates counting each country as one, so that small countries have the same weight as large countries in the summary statistics. The much larger values in columns 3 and 4 are due to the fact that emigration rates (both actual and desired) are larger in small countries.

\section{$<<$ Table 1 about here $>>$}

Three interesting facts emerge from these aggregate statistics. Focusing on the weighted figures, actual emigration rates between 2000 and 2010 as a share of the world population were fairly small. Only 0.4 percentage points of the native non-migrant population without college education migrated between 2000 and 2010, compared to 3.9 percentage points of those with college education. Desired emigration rates were larger. About 8.5 percent of noncollege educated and 16.2 percent of college educated said that they were willing to migrate (if they had an opportunity) but they did not do so in the considered period. Most strikingly, there was a much larger difference between non-college and college educated in actual rates (ratio of almost 10 to 1 ) than in desired rates (ratio of 1.9 to 1 ). This is even more notable when we consider the simple averages in columns 3 and 4 . This fact suggests that the low migration rates of non-college educated may not be due to a difference in perceived benefits/costs of migrating, but may rather be explained by the fact that those searching for migration opportunities without a college degree have a much harder time finding them. An additional interesting implication of the simple averages is that if all people who say that, ideally, they are willing to migrate would do so, the migration rate of college educated would still exceed that of non-college educated, but emigration rates of the two groups would be much closer. However we should be cautious in considering the desired (potential) migration rate as realizable under any circumstances. Our results below show that even free labor mobility policies do not seem to move potential and actual migration rates any closer together. While "potential migration" is an interesting concept to identify migration searchers, the frictions and hurdles preventing its translation into actual migration could be pervasive and hard to reduce, at least within the plausible range of policies and institutions. 
The lower part of Table 1 shows, instead, summary statistics on actual and desired migration rates from the perspective of the receiving country. The actual and desired flows (and stocks in 2000) of migrants are aggregated by country of destination (or desired destination) and divided by the native resident population of the destination country. Hence, those two rows show actual and desired "immigration" rates for the 30 destinations considered, averaged either by weighting by the destination country population (columns 1 and 2) or without weights (columns 3 and 4 ).

As stated above, the considered 30 destination countries receive about two thirds of the actual, worldwide migration stock, and 82.5 percent of the worldwide stock of high-skilled migrants. Yet, they include less than 20 percent of the world population so that the immigration rates for these countries are much greater than the emigration rates for the origins in our sample. During the 2000-2010 period, immigration of non-college educated into the considered destination countries corresponded to 2.4 percent of their aggregate non-college educated population as of 2000, compared to 6 percent for college educated. Desired immigration among non-college educated, i.e. the size of the inflow of all "willing" migrants, would amount to 42 percent of the native non-college educated population. For college educated, desired immigration equals 26 percent of the receiving country population. In this case there are more potential non-college educated migrants to our destination countries than there are college educated. The reason is that, while the emigration rate from almost any country is larger for college educated, there are many more non-college educated in the sending than in the receiving countries so that - from the destination point of view - the flow in percentage of non-college educated would be much larger. Hence, if all people who are willing to migrate would follow on their desire, the inflow of immigrants into the considered receiving countries would be much less skill-intensive than it is today. For most countries, it would still be college intensive but in some countries (such as the US), the inflow would become much larger and non-college intensive. Let us emphasize, before moving to the analysis of individual countries, that the data used to construct desired emigration rates, only use the information about people's willingness to migrate. On the other hand those used to calculate desired immigration rates use also the information on the most preferred country of migration. In as much as potential migrants are willing to migrate to other (less preferred) countries, or do not know exactly which country they would like to migrate to, there would be significantly more imprecision in the second measure than in the first. Coun- 
tries that do not top the lists of most preferred but could still be desirable destinations, in particular, could receive significantly more immigrants than these figures suggest, if they unilaterally opened their borders.

\section{Sending and receiving countries}

Desired and hence potential migration rates are significantly larger than actual migration rates. Here we show preliminary evidence that they are also correlated with those. Table 2 shows the actual net immigration rates and the desired immigration rates - desired from the point of view of migrants for each of the 30 considered receiving countries. First, note that the actual net immigration rate for non-college educated is usually below 10 percent and sometimes quite small (or even negative in the presence of return migration). In contrast, the immigration rate of college educated is found to be usually quite large, on average it is 35.8 percent. The United Arab Emirates form a clear outlier, attracting immigrants in much larger numbers than the native population both among more and less educated. The labor force of professionals and workers in these countries has typically been built by attracting immigrants. Australia, Canada, Ireland and the United Kingdom, on the other hand, attracted a large inflow of college educated and had a very skillintensive immigration in the 2000-2010 period. These data confirm previous studies (Docquier et al., 2014; Artuç et al., forthcoming) in finding that, for essentially all migration receiving countries, the flow of recent immigrants was college educated intensive relative to the native population. The third column defines immigration as "skilled" ("unskilled") if the net immigration rate between 2000-2010 was larger for college (non-college) educated. All but two countries in our sample (US and New Zealand) were characterized by skilled immigration in the 2000s. The remaining columns calculate the desired immigration rate for the same set of receiving countries 2000-2010. While both rates are much larger than the actual ones, non-college educated desired immigration is eight times as large as actual, while the ratio for college educated is less than three. As a result, while the majority of countries would still be facing skilled desired immigration, ten countries would switch to primarily low-skilled immigration if all those who are willing to migrate were to do so leading to a much smaller over-representation of college educated among immigrants. The US exhibits desired immigration rates heavily biased in favor of unskilled, mainly because it is the most popular migration destination for most people in the world and because, on average, there are 
many more non-college educated than college educated in the world.

$$
<<\text { Table } 2 \text { about here }>>
$$

Preliminary evidence also shows high correlation between potential migration and actual emigration rates in Figures 1 and 2. These figures report scatterplots of actual and potential emigration rates from the 138 sending countries and the OLS regression lines describing their correlation separately for non-college and college educated. By aggregating all destinations we are reducing also the error in assigning potential migrants to one or another destination. We observe a positive and very significant correlation for both college and non-college educated. The regression line for the college educated, however, has a slope of 0.93 and potential migration rates explain most of the variation of actual rates $\left(\mathrm{R}^{2}=0.969\right)$. For non-college educated, the slope is only 0.24 , though still very significant $\left(R^{2}=0.378\right)$. We can summarize this stylized fact by saying that countries with a very large net emigration rate of college educated are those where many college educated want to emigrate. To the contrary, for less educated, the percentage of people willing to emigrate is always much larger than (and less correlated to) the percentage of actual migrants. This is a clear sign that desiring to emigrate is far less effective in realizing emigration for non-college educated than for college educated.

\section{$<<$ Figure 1 about here $>>$ $<<$ Figure 2 about here $>>$}

Figures 3 and 4 show similar scatterplots for immigration rates in the 30 destination countries. The scatterplots are more noisy implying that our data about willingness to migrate to a specific country may be less precise than in capturing a general willingness to migrate, as mentioned above. Nevertheless, potential immigration rates have a significant and positive effect on actual immigration rates. Yet, for each increase in the potential immigration rate of non-college educated by one percentage point of the native population, only 0.05 percentage points of actual immigrants would materialize. For each percentage point of potential college educated, instead, the country would receive almost 0.2 percentage points of actual immigrants. This difference between college and non-college in the percentages of potential migrants turning into actual migrants will prove to be a very pervasive feature of international migration. It survives the inclusion of many controls, it is present both in aggregate and bilateral rates and it is common to poor and not so poor countries of origin. 


\section{$<<$ Figure 3 about here $>>$ \\ $<<$ Figure 4 about here $>>$}

\section{FRAMEWORK}

As described above, we organize our data into aggregate groups by country of origin $o$, destination $d$ and education categories: $h$ (college educated), and $l$ (non-college, or less educated). The native population of reference is defined as the total number of individuals aged 25 and over, born and residing in country $o$ in the year 2000, (the first year of our sample). We call these groups $N_{o}^{h}$ and $N_{o}^{l}$ respectively for more and less educated. The desired migration rates, $w_{o, d}^{h}$ and $w_{o, d}^{l}$ then capture those who revealed themselves as willing to migrate to country $d$ yet who were still residing in $o$ between 2007 and 2013, expressed as shares of $N_{o}^{h}$ and $N_{o}^{l}$. The net migration rates $m_{o, d}^{h}$ and $m_{o, d}^{l}$ then equal the net flows of actual migrants from country $o$ to country $d$ in the period 2000-2010, relative to the initial population in 2000. The sum of these two groups constitutes the total of potential migrants, i.e. $P_{o, d}^{h}$ and $P_{o, d}^{l}$, which, standardized by the initial population, correspond to the potential migration rates denoted by $p_{o, d}^{h}$ and $p_{o, d}^{l}$.

Potential migrants should have higher utility (accounting for migration costs and gains) from living/working in country $d$ than in their country of birth $o$. This is the group identified by migration scholars as "aspiring" or "intended" migrants. Our main specification considers the revealed migration preference for a specific destination country $d$. This may be a strong assumption (De Jong, 2000, De Jong et al., 1996) which is relaxed when we analyze the overall migration potential (rather than bilateral) by aggregating all potential migrants in a country of origin. Allowing for heterogeneity in preferences across individuals, but assuming that all individuals (i) value income from higher wages and higher probability of employment, and (ii) incur higher costs when moving farther and to more different countries, implies that - after controlling for country of origin characteristics - the share of people who would potentially migrate from $o$ to $d$ among all individuals, $p_{o, d}^{s}$, depends positively on the returns and negatively on the costs of migrating from $o$ to $d$ (see Borjas, 1987; or Grogger and Hanson, 2011 for a similar framework). So we assume that people account for all perceived costs and benefits of migration when revealing whether they would like to migrate or not and to which country. Also, the willingness to move to a country 
shows that individuals know about the opportunities in that country, and therefore the availability of information about that country can be a crucial determinant of willingness to move there. In general, we can write:

$$
p_{o, d}^{s}=f\left(\text { Returns }_{d}, \text { Cost }_{o, d}, \text { Info } o_{o, d}\right)
$$

We then consider a linear approximation of (1) which expresses the potential migration rate, $p_{o, d}^{s}$, as a linear function of factors affecting the returns in a specific destination, the bilateral cost of migrating and the flow of information from country $d \cdot{ }^{[5]}$ Following the economic literature (as in Borjas, 1987; Hatton, 2005; Mayda, 2010) we consider wages (approximated by income per person) and employment opportunities (approximated by employment/population ratio) in country $d$ as the main determinants of the economic returns to migration. Following the economic and anthropological literature (e.g. Putterman and Weil, 2010; Spolaore and Wacziarg, 2009) we include measures of distance and proximity in geographic, language, genetic and cultural space to capture migration costs. Finally we consider the size of the destination country and the presence of a pre-existing diaspora of migrants from country $o$ as the main sources of information about the country. The diaspora presence can also directly reduce migration costs by providing easier assimilation. We can, therefore, write relation (1) as a linear specification of the following form (for $s=h, l$ ):

$$
p_{o, d}^{s}=\alpha_{o}^{s}+a_{1}^{s} y_{d, 2000}+a_{2}^{s} e_{d, 2000}+a_{3}^{s} \text { Dist }_{o, d}+a_{4}^{s} \ln \text { Pop }_{d}+a_{5}^{s} N e t w_{o, d}+\epsilon_{o, d}^{s}
$$

In equation (2), $\alpha_{o}^{s}$ is a set of 138 country of origin dummies that capture heterogeneity of people and preferences and economic conditions across origins. The term $y_{d, 2000}$ captures per capita income (GDP) in the destination country in PPP US $\$$ as of the year 2000. The term $e_{d, 2000}$ is the ratio of employment to population in working age as of 2000 in the destination country. These variables proxy (imperfectly) for the expected income and employment probability of a migrant and determine the economic attractiveness of a destination. Their cross-sectional differences are very large and one can plausibly assume that individual decisions on long-term migration are informed by these differences. $D i s t_{o, d}$ is a set of bilateral variables capturing geographical distance, such as common border, language or colonial origin and measures of genetic, religious and legal distance across countries. 
Those factors affect the transferability of skills, cultural barriers and moving costs, hence influencing costs and benefits from migration. The term $\ln P o p_{d}$ captures the size of the receiving country which affects its "visibility" to potential migrants. Netwo, $w_{o, d}$ finally, is a measure of the size of the stock of existing migrants from $o$ in $d$ in 2000 expressed as percentage of the population in the origin country. This is a first approximation of the connection with the country of destination, which can affect information and reduce costs of settling and hence could affect potential migration. The term $\epsilon_{o, d}^{s}$ captures measurement error.

Specification (2) is similar to what is usually estimated in the economic literature using actual migration data (Grogger and Hanson, 2011; Beine et al. 2011; Ortega and Peri, 2013). Our data allows us to go one step further. The actual migration "action" requires that "a migration opportunity" becomes available to potential migrants. This could be the opportunity of a visa or a migration permit, or it may involve a study, working or career opportunity. A successful migration episode, in other words, involves the matching of a migration opportunity at destination $d$ and a potential migrant from country $o$, from the pool $p_{o, d}^{s}$. Hence, we express actual migration, $m_{o, d}^{s}$, as the number of successful potential migrant-opportunity matches, which depends positively on the size of the population willing to migrate to $d, p_{o, d}^{s}$, and on the opportunities for migrants arising in the 2000-2010 period in the destination country, $v_{d}^{s}$. Those viable opportunities (hence the letter $v$ ) are usually not specific to people in country $o$, hence we only have a subscript $d$ but in practice some bilateral factors could improve the availability of those opportunities to some specific countries of origin. In general we write:

$$
m_{o, d}^{s}=m\left(\begin{array}{c}
p_{o, d}^{s}, \\
++ \\
+
\end{array}\right.
$$

The superscript $s$ permits differentiating between college and non-college educated. This framework allows us to explore whether economic growth (captured by real income per capita growth, $g y_{d}^{00-10}$ ) or employment growth (captured by the growth of employment relative to the population, $g e_{d}^{00-10}$ ) in the period 2000-2010 in the destination countries contributed to actual migration, once we account for the pool of potential migrants for that country. Fast growth of income per capita or growth of employment are driven by productivity growth, which would increase demand for labor in a destination country, creating opportunities (jobs, study, business) for immigrants. These vacancies could be matched to potential migrants willing to move to that 
country. Potential migrants are a stock (share of those who would migrate) measured at a specific point in time. This is why their size depends on a static comparison of income per person, capturing long-run present discounted values. Actual migrants, on the other hand, are a flow (the subset that realize migration potential within a period). Hence, the creation of opportunities to migrate which affects the flow is correlated to GDP and employment growth at destination. Such flows, however, may have a different impact on sending countries depending on the stock of potential migrants. New jobs and growth of productivity are needed to produce new opportunities for an existing stock of potential immigrants. We will test the premise that income levels (rather than growth) affect potential immigrants while income growth (rather than levels) affect net migration for given potential immigrants.

Potentially important in translating potential into actual migrants are also the policies in the destination country. We analyze the role of some specific policies $\left(\right.$ Policy $\left._{o, d}\right)$. In particular, we consider visa waiver policies that regulate access to a country for all foreigners as well as free mobility of labor which is the closest policy to open borders. It is worth noticing that these two policy variables only affect entry conditions and not the conditions of stay in the destination countries (e.g. employment, taxation, etc.). Clearly the details and nuances of immigration policies are large and very different across countries (for more sophisticated indices, see Ortega and Peri, 2013; Helbling and Vink, 2013) and our simple indicators may not be capturing important aspects of those policies. Finally, we can analyze whether the pool of potential migrants and economic and policy variables interacted with each other to increase the matching rate, and hence the realized migration rate. Linearizing the matching function given in equation (3), including country-of-origin fixed effects $\beta_{o}^{s}$ and substituting the potential determinants of opportunities of migration, $v_{d}^{s}$, we have:

$$
m_{o, d}^{s}=\beta_{o}^{s}+b_{1}^{s} p_{o, d}^{s}+b_{2}^{s} g y_{d}^{00-10}+b_{3}^{s} g e_{d}^{00-10}+b_{4}^{s} \text { Policy }_{o, d}+\varepsilon_{o, d}^{s}
$$

where $\varepsilon_{o, d}^{s}$ is the residual term.

While we consider economic growth and receiving-country policies as the key determinants of migration opportunities for potential migrants in the empirical analysis we will also include bilateral cost variables, network variables and other economic variables as controls. In our empirical analysis we will estimate the basic equations (2) and (4) in order to determine which factors 
affect the size of the pool of potential migrants and which factors affect their matching with migration opportunities.

\section{DETERMINANTS OF POTENTIAL MIGRATION RATES}

We first estimate several versions of equation (2) to analyze the determinants of potential migration rates, including a progressively larger set of determinants and controls. The dependent variable is the potential emigration rate for each skill group $s$ from country $o$ to country $d$ in the period 2000-2010, $p_{o, d}^{s}$. As some values of the actual net emigration rate, $m_{o, d}^{s}$, are negative (due to return migration or migrants' mortality), we set them to zero before calculating the potential rate and, similarly, we censor the observations on bilateral migration at a value equal to the average plus five standard deviations as some of them are relative to very small countries and hence excessively noisy. Let us emphasize that, while customary in this literature, the identification of causal effects using a cross-section estimation has to be taken with caution. While controlling for country of origin specific factors and for important bilateral factors, there are still unobserved bilateral and destination-specific factors that may bias the coefficients. While we will sometimes use a causal language referring to the explanatory variables as "determinants of potential migration" we are well aware that our estimates mainly identify correlates of potential migration and migration flows.

Table 3 shows summary statistics for the migration variables, net emigration rates and potential emigration rates and for the stock of migrants, divided by the native population and for the share of natives with at least one member of the household who migrated abroad during the previous five years $^{[6]}$. The potential bilateral migration rate for non-college educated has an unweighted average value equal to 0.49 percent, compared to 0.71 percent for college educated ${ }^{[7]}$. The actual bilateral migration rate for non-college educated was on average 0.05 percent, while for college educated the average bilateral rate amounted to 0.21 percent. These rates are small but capture bilateral (not aggregate) migration net flows (not stocks) of migrants. Each country of origin has 30 destinations. Hence, average bilateral rates of 0.05 percent and 0.21 percent imply migration rates of 1.5 percent and 6 percent of the native population in total over the $2000-2010$ period. ${ }^{[8]}$

$$
<<\text { Table } 3 \text { about here }>>
$$


Tables 4 and 5 display estimation results for non-college and college educated, respectively. They show the coefficients on economic, network and policy variables in regressions whose dependent variable is the potential emigration rate for the two skill groups separately. In each regression we include a set of 138 countries of origin effects to account for heterogeneity in characteristics and conditions in the countries of origin. We also include the logarithm of population at destination to account for the size of the destination country, which could affect the potential to migrate there if people are more likely to know of larger countries' opportunities relative to smaller ones. We also cluster the standard errors at the country of origin level to allow residuals to be correlated among individuals in the same country of origin. We progressively include more controls from column 1 to 6 . In column 1 we only include the measures of migrant networks (i.e. the stock of natives from country $o$ residing in country $d$ as of 2000, in percentage of the native population and the percentage of the native population with a household member abroad), income per person (thousands of 2000 US \$ in PPP) and the employment rate in the destination country. In column 2 we allow the dependent variable to have negative values (i.e. the negative net migration rates were not set to zero). In column 3 we add some basic geographical and cultural distance controls: the logarithm of bilateral distance, a common border dummy and a dummy for a common official language. In column 4 we also add variables proxying for more specific dimension of cultural and institutional distance between countries. They involve a dummy for common legal origin, one for common currency, the number of landlocked countries in the pair, a measure of religious distance and a measure of genetic distance, taken from Ortega and Peri (2014) and Spolaore and Wacziarg (2009). These specifications identify the role of economic variables, networks and costs driven by differences in determining potential migration rates. In column 5 we include also the 2000-2010 growth rate of income in the destination country to check whether it affects potential migration. As mentioned above the comparison of benefits and costs in the decision to migrate should be based on long-run expectations, captured by average differences in income per person more than by recent growth rates. Specification 6 includes two measures of immigration policies: a dummy for those countries with free labor mobility between them in 2000, namely the EU18 countries among themselves and with Switzerland, the Nordic countries (Denmark, Sweden, Norway, Iceland and Finland) among themselves, and a dummy for those countries having a visa waiver agreement for travel between them (Neumayer, 2006). Finally, in 
column 7 we include only non-rich countries in Asia, Africa and Latin America as sending countries and we analyze whether the determinants of potential migration from poorer countries systematically differ from those estimated using the whole set of countries. The results reported in the tables focus on the role of economic, network and policy variables. While it is important to control for geographical and cultural variables, those are hard to change or to affect. Therefore, we include them as controls and comment only on some main coefficient estimates but we do not report their coefficients in the tables.

$$
\begin{aligned}
& <<\text { Table } 4 \text { about here }>> \\
& <<\text { Table } 5 \text { about here }>>
\end{aligned}
$$

\section{Migrant networks and economic incentives}

Let us first focus on the effects of network and economic variables on potential migration rates. The first two rows of Tables 4 and 5 show the impact of the stock of existing migrants abroad as of 2000 and the effect of the share of people in the country with a household member abroad. While the first variable was constructed based on the data of Artuç et al. (forthcoming) and Brücker et al. (2013) on the stock of migrants, the second is obtained from the Gallup poll data. It represents the share of natives in country $o$ who said they had a household member who migrated to country $d$ within the previous five years. This allows us to link individuals with their more recent and more direct "connections" then construct an aggregate measure of it. This measure of networks is related more directly to the possibility of natives receiving information about country $d$ and assistance once in the destination. The correlation between these network variables equals 0.16 for the college-educated and 0.43 for the less educated. Both network variables have a positive and significant effect on potential migration for college and non-college educated (rows 1 and 2 of Tables 4 and 5). Both explanatory variables are divided by their standard deviation so that the coefficient shows the impact on potential migration rates from increasing the variable by one standard deviation. Table 4 reveals that an increase in the stock of natives in country $d$ by one standard deviation increases the potential migration rate of non-college educated to that country by 0.73 to 0.95 percentage points, while the effect for college educated is around 1 percentage point. Increasing the share of people with household members in country $d$ by one standard 
deviation increases the potential migration rate of college educated by about 2 percentage points and of non-college educated by 1 percentage point. Recall that the average migration rate for non-college (college) educated was 0.49 percent (0.71 percent).

Hence, potential migration is very responsive to the stock of existing compatriots and household members abroad. This confirms previous evidence (e.g. Hanson and McIntosh, 2010; Hatton and Williamson, 2005) and emphasizes the additional effect of recent household links in encouraging potential migration. For many important corridors, the network effect is a key correlate of potential migration. For example, potential migration rates from Mexico to the United States are equal to 16.0 and 17.5 percent for college educated and the less educated. Two thirds of those values can be explained by network effects. Indeed, the Mexican diaspora in the United States amounts to about 5.2 million people, representing 11.2 percent of the Mexican population aged 25 and over (6.3 standard deviations in the aggregate network variable). The proportion of Mexican households having a household member who migrated in the previous five years is equal to 2 percent for college educated and 4.5 percent for the less educated (i.e. 2.5 and 5.6 standard deviations). Obviously, causal relationships are difficult to establish in a cross-country framework and our estimates are more correlation than causation. Taken at face value, our estimates suggest that each network effect increases the potential migration rate by 5 to 6 percentage points. As for the Turkey-to-Germany corridor, the potential migration rate of low-skilled Turks equals 3 percent. Again, two thirds of this rate (2.2 percentage points) is explained by the network effects. An important caveat is that the stock of migrants abroad may capture not only network effects but also the persistence of bilateral relations that have increased migration in the past and continue to do so. Controlling for that, the measure of people with household members recently migrated abroad has an additional and important effect. It could be more directly connected to the diffusion of information and the presence of potential support at destination, but could also reveal some aggregate collective decision of families due to unobserved factors affecting their willingness to migrate. The fact that we control for country of origin effects, and that we focus on the aggregate (and not family-level) effects reduces the risk of omitted variable bias.

Crucial to our analysis is the role of economic variables in determining potential migration. In the section describing the theoretical framework we assumed that income per person and the employment rate at destination 
proxy for the long-term expected gains of migrating as they allow migrants to predict their future income and probability of employment. The large international differences in these variables are likely to be known to potential migrants and hence to affect their preferred destination. It is therefore reassuring to see that both variables strongly affect potential migration rates for both more and less educated. The coefficients are similarly significant for college and non-college educated, although somewhat larger for the first group. From Table 4 we see that a difference in income per person of 10,000 PPP US \$ in 2000 (which equals one standard deviation in the income per person distribution of the 30 destination countries and corresponds to the difference in income per person between the UK and the US) increases the potential migration rate by 0.20 percentage points for the less educated (for an average of 0.49 percent) and by 0.30 percentage points for college educated (for an average of 0.71 percent). An increase in the employment rate of 10 percentage points (also close to the standard deviation across destination countries) would increase potential migration by 0.05 percentage points for less educated and by 0.10 percentage points for more educated. The estimates are very significant and stable across specifications. Income per capita - for which information is more easily available - has the largest effect and the response of the less educated to differences in that variable is only 50 percent smaller than the response of college educated. This difference can be due to the fact that in richer countries, highly educated get a higher absolute wage premium implying that they would be more willing to migrate (Grogger and Hanson, 2011). This confirms that less educated migrants, when choosing whether to look for migration opportunities, are driven by the same considerations (income and jobs) as college educated and their response to those variables is also quantitatively similar to the response of college educated.

The estimates in Tables 4 and 5 reveal two other important features of potential migration. First, focusing on the last column 7 in which the sample is limited to non-rich countries of origin (outside of Europe, North America and Oceania), we see that the responses of desired migration rates from these countries to income per person and employment rates in the destination are very similar to the responses obtained with the full sample. College and non-college educated migrants from poor countries respond to income and employment at destination in a similar way as migrants from other countries. The only variable that seems to matter somewhat more for potential migrants in poor countries is the stock of nationals having migrated previously to $d$. Networks measured as the share of natives with a household member abroad, 
however, have the same impact on poor countries as in the full sample. This possibly implies that the stock of past migrants reveals past preferential relations between the poor country and the destination (driven by cultural, colonial or other non-observable ties).

The second interesting fact is revealed by columns $5-7$. While income per person levels as of 2000 have a strong and positive correlation with potential migration, the growth rate of income per person at destination in 2000-2010 has an insignificant effect. Potential migrants are less affected in their preferences for migrating and where to migrate, by recent/potential economic performance of the destination. The US and Canada remain very attractive destinations for potential migrants from Guatemala, even in decades when their economy was not growing very fast. The marginal effect of growth over a decade on cross-country differences in GDP per person is small and hence does not affect much the pool of potential migrants. This is strongly confirmed by our results. We show evidence below that faster growth increases actual migration rates to a country. Our framework allows us to understand why. Faster growth means more opportunities for migrants as new firms and higher productivity generate vacancies and migration opportunities in destination countries. Whereas the flow of actual migrants benefits from that growth, the stock of potential migrants is not much affected.

\section{Geography, Culture and Policies}

If the decisions to be a potential migrant is driven by cost-return calculations only and it is not affected by the probability of securing an opportunity to migrate, we would not expect the policy variables in the destination country, which affect only the opportunities but not the costs/benefits once migrated, to play a crucial role in determining potential migration. Policies are, however, expected to play a role in determining actual migration. Variables measuring geographical, cultural and institutional distance, on the other hand, should affect the cost of migration through their impact on the transferability of skills, and could as such have an effect on potential migration.

In columns 4 and 5 we include several controls capturing geography, culture and institutions. We do not show their coefficients in the tables but we comment on their estimates here. First, the addition of these controls does not change the size and significance of the coefficients of economic and network variables. Second, we should keep in mind that we are already controlling for the past stock of migrants and presence of household members 
abroad. Those clearly capture a large part of the effect of geography, culture and institutions, which are slow to change or do not change at all, on past migration. Worth mentioning is that the logarithm of distance is not significant for either more or less educated. Common language is the only variable significant for potential migration rates of both college and non-college educated (with a larger coefficient, 0.88 , for college educated than for the less educated, 0.44). No other geographical variable is significant at the 1 percent level for non-college educated, while colonial ties $(0.48$, standard error of 0.17 ) and genetic distance (t-statistic of -4.93) appear significant for potential migration of college educated. These checks confirm the relevance of geographical, cultural and historical ties for bilateral migration as established in the empirical literature (see among others Hatton and Williamson, 2005; Pedersen et al., 2008; Mayda, 2010; Grogger and Hanson, 2011). ${ }^{[9]}$ Here we are more interested in verifying that after including them as controls for bilateral migration costs, the magnitude and significance of the main economic variables affecting expected gains from migration are preserved. The results of columns 3 and 4 in Tables 3 and 4 confirm that this is the case as the coefficients on the income per person and employment rates remain virtually unchanged.

In column 6 of Tables 4 and 5 we introduce two policy variables. The first is a variable aimed at capturing free labor mobility across countries. The second is a dummy indicating a visa waiver agreement when traveling between the countries. Other papers (e.g. Mayda, 2010; Ortega and Peri, 2013) included several measures of immigration policies capturing the restrictiveness of provisions such as visa policies, quotas or asylum policies to analyze how they affect migration. Here we take a simpler approach. Since it is very complicated to measure or even rank the restrictiveness of immigration policies, we identify only two policies, which can substantially affect cross-border mobility in general, and for working purposes in particular. Specifically, we consider the elimination of all immigration restrictions to labor mobility between countries and the presence of a visa waiver agreement between countries that allows people to visit without obtaining a visa (shown by Bertoli and Fernández-Huertas, 2013, to be an important variable in determining bilateral mobility). In the presence of free labor mobility, people from a country can work freely at the same conditions as natives in a foreign country. This type of policy was established across countries of the European Union by the 1992 Maastricht Treaty. Moreover, since the 1990's, Switzerland and the Nordic countries of Europe (Norway, Sweden, 
Finland, Denmark and Iceland) have signed bilateral agreements ensuring free labor mobility of their workers with all the EU countries. Hence, we include bilateral dummies to capture the free mobility arrangements across these countries which were in place as of 2000, the initial year in our analysis.

The estimates in column 6 reveal that neither the presence of free migration policies nor visa waiver agreements affect the pool of potential migrants both for college and non-college educated. While the presence of such bilateral agreements may proxy also for other bilateral policies, it makes sense to find that potential migration is not affected by them. Note that while these policies affect the probability of having an "opportunity" to migrate to a specific country, they do not affect costs or benefits from such opportunity. Potential migration reflects preferences, costs and benefits for bilateral migration choices in the presence of an opportunity. Policies affecting the opportunities to migrate should not affect that calculation.

\section{Robustness checks}

In Table 6 we subject our estimates of the determinants of potential migration rates to a number of robustness checks. The table shows specifications including all the controls from column 5 in Tables 3 and 4, to which we alternatively add different controls or for which we modify the sample in different specifications. Columns 1 to 3 show the results for the less educated, while columns 4 to 6 show those for college educated. In specifications 1 and 4 we include continent-destination dummies in order to take into account the fact that destination countries in Europe or North America might have particular policies or characteristics in common, and in order to accommodate the possibility that the choice of migration within a continent is correlated (as pointed out by Bertoli and Fernández-Huertas, 2013). The estimates of the main coefficients are again stable in magnitude and significance. Only the employment rate becomes less significant, which is certainly due to the smaller within-continent variation of this rate across countries. The growth of GDP per person even becomes negative in this specification, confirming that people do not account for recent performance when choosing their "desired" migration countries, but rather compare long-lasting differences in income per person.

Columns 2 and 5 analyze whether considering only "desired" migration rates rather than potential (thus excluding people who actually migrated) changes the effect of economic determinants. This allows us to verify that the 
subset of actual migrants is not a "special" group among potential migrants in terms of their response to economic incentives. For both college and noncollege educated the estimates are similar to those of column 5 in Tables 4 and 5, confirming that those economic variables affect all potential migrants, independent of whether they succeed in migrating or not. Finally, as the data on desire to migrate are based on Gallup Polls that include only a few hundred people in some small countries, we include a check on the reliability of those data. In particular, we drop from the regressions all the bilateral desired migration rates based on less than 75 respondents (for the less educated) and less than 37 respondents for college educated. This reduces the sample (inclusive of all non-missing controls) from 3,744 observations to 3,278. The point estimates of the effects, however, show that the results are robust even to selecting only the most reliable bilateral potential migration rates and that economic and network variables play the same important role.

$$
<<\text { Table } 6 \text { about here }>>
$$

\section{POTENTIAL MIGRANTS, MIGRATION OPPORTUNITIES}

\section{AND ACTUAL MIGRANTS}

The analysis so far shows that income per person, employment probability and the presence of networks from the same country of origin (either measured as the stock of previous immigrants or as the share of natives with a household member abroad) are robust and significant determinants of potential migrants. They contribute importantly to determining the size of the pool of people searching for migration opportunities. But how do these potential migrants turn into actual migrants? What factors affect the actual migration rates on top of the potential migration rates? Which share of potential migrants become actual migrants? These are the questions we will focus on in the present section.

In Tables 7, 8, 10 and 11 we estimate variations of equation (4) in which the dependent variable is the actual migration rate from country $o$ to country $d, m_{o, d}^{s}$, with the potential migration rate as the first explanatory variable. We include an array of destination country characteristics that may affect migration opportunities and hence the number of actual migrants. We always control for country of origin fixed effects. Tables 7 and 8 show the results of the main specifications, for the less educated and college educated, 
respectively. Table 10 analyzes whether labor mobility policies, networks and growth of economic opportunities in the destination countries interacted with potential migrants affect actual rates. Table 11, finally, considers whether actual migration from low-income countries of origin (in Asia, Africa and South America) responded differently to potential migration and other factors potentially affecting migration opportunities.

\section{Economic opportunities and migration policies}

The basic specification (1) in Tables 7 and 8 includes only country of origin fixed effects, the potential emigration rate and growth of GDP per person and of employment probability (employment/population at working age) in the destination countries. Growth in GDP per person between 2000-2010 and potential migration rates turn out to be the most relevant and significant determinants of actual migration rates. Growth in the employment rate between 2000-2010 appears to have a less relevant impact that is sometimes even negative for college educated migrants. As a check, we included the GDP level, bilateral geography and cultural controls and found neither significant effects nor impacts on the other coefficients. Let us focus, therefore, on the two most significant variables: growth of GDP per person and the potential migration rate. What is noteworthy is that while those variables affect migration rates for both non-college and college educated, the impact is much stronger and significant for the latter. While an increase in potential migration rates by 1 percentage point produces an increase in actual migration by only 0.04 percentage points for the less educated individuals, it is associated with an increase by 0.13 percent for college educated. Similarly, an increase in GDP per person by 20 percent in the decade (equivalent to 2 percent per year which is roughly the mean and standard deviation of this variable across destination countries) increases actual migration rates by 0.016 percentage points for college educated and by only 0.004 percentage points for the less educated. Recall for comparison that the impact of GDP per capita levels at destination on potential migration rates were almost the same for college and non-college educated.

$$
\begin{aligned}
& <<\text { Table } 7 \text { about here }>> \\
& <<\text { Table } 8 \text { about here }>>
\end{aligned}
$$

Overall we find that the response of college educated actual migration rates to growth rates and to potential migration rates is three times larger 
than for non-college educated. Hence, on average, a much larger share of college-educated potential migrants turns into actual migrants, and favorable economic conditions at destination increase their actual migration rates much more than those of less educated individuals. This implies, for instance, that in spite of a much higher potential migration rate of non-college educated from India to the US (around 1 percent) than from India to Spain (around 0.003 percent) - this will only translate in an actual rate to the US 0.05 percent higher than the one to Spain. For college educated, in contrast, the desired migration rate to the US, which equaled 8 percent relative to Spain (equal to 0.02 percent), predicts a 1.04 percent higher actual migration rate to the US than to Spain. The actual difference in migration rates for college educated from India to the US and to Spain is 2.7 percent, and $40 \%$ of it can therefore be explained by the difference in the pool of potential migrants to each country. The difference in potential migration rates of non-college educated to the two countries, on the other hand, did not explain much of their actual difference.

To illustrate the importance of the difference in realization rates between college-educated and less educated potential migrants, we simulated the net immigration rates under the assumption that the migration opportunity matching rate of the less educated was equal to that of college educated (i.e. that they had a realization rate of 0.13 instead of 0.04 ). Our simulation assumes that corridors with zero migrants remain empty. This can be thought as a drastic policy experiment (such a policy is clearly not on the political agenda) that equalizes the migration opportunities of college and non-college educated. Table 9 presents the simulated realization rates by destination country. Columns 1 to 3 show the change in immigration flows, whereas changes in immigration rates are obtained by comparing columns 4 and 5 (for the less educated) and columns 6 and 7 (for all migrants). The total inflow of less educated migrants to our destinations increases by 14.7 million (+117 percent) of whom 39 percent would move to the United States. The other important destinations are Spain, Saudi Arabia, France, Italy and Germany. In relative terms, the largest changes in low-skilled immigration rates are observed for New Zealand (+10.3 percentage points), the United States (+7.8), Switzerland $(+6.2)$ and in the Persian Gulf countries. The same patterns are obtained for total immigration rates.

$$
<<\text { Table } 9 \text { about here }>>
$$


It could be argued that measuring migration potential in a bilateral way results in measurement error and hence in an underestimation of the effect of potential migration on actual migration if potential migrants have a clear preference for migrating but a weak preference for specific countries. To assess the severity of this bias, we redefine potential and net migration aggregated over all countries of destination and run a number of specifications keeping only the country of origin dimension. In order to avoid too demanding specifications (as we only have 138 observations) we only include the stock of people with a household member abroad and GDP per person in the country of origin as controls. Table A2 in the appendix shows the estimated coefficient of potential rates on actual rates. In the specification with networks and income controls, the estimate of the rate at which potential migrants turn into net migrants is 0.18 for college educated and 0.03 for non-college educated. These rates are not too far from those estimated using the bilateral definitions ( 0.13 and 0.04 respectively), suggesting that the impact on actual migration rates from considering aggregate instead of bilateral potential migration is fairly similar. While bilateral preferences may be imprecise, they still seem to reveal useful information on the potential destination of migrants.

Coming back to our regression results, column 2 of Tables 7 and 8 analyze whether the level of GDP per person and the employment rate in the destination country affect actual migration for either skill level, after controlling for potential migrants and GDP growth. The estimates reveal that destination country GDP per person and employment probability do not matter in determining opportunities, once potential migrants are controlled for. This confirms the presumption that income levels in the destination country only affect migration through their effect on potential migrants (shown in Tables 4 and 5), as they serve as proxies for present discounted return from migrating. Also, in line with Grogger and Hanson (2011), positive selection in actual migration is positively associated with the GDP level at destination. A 10,000 PPP US $\$$ increase in GDP per capita increases potential migration by 0.30 and 0.20 percentage points for college educated and the less educated, which, in turn, increases actual migration by 0.026 and 0.008 percentage points (i.e. $0.30 \times 0.136$ and $0.20 \times 0.04$ ), respectively. A simple numerical experiment reveals that the total migration flow would be 21 percent greater if income per capita in the 30 destination countries (an average of 27,606 PPP US \$) was equal to the US level (i.e. 39,175 PPP US \$). College educated would be more responsive $(+25$ percent $)$ than the less educated $(+17$ percent). 
Column 3 analyzes whether the presence of family networks affects opportunities to migrate, after controlling for potential migration rates. In Tables 4 and 5 we saw that networks were crucial to increase the pool of potential migrants to a destination country. The impact of networks, measured as the stock of existing migrants or the share of natives with a household member abroad was estimated to be very large. A one standard deviation increase of the network in country $d$ corresponded to a one percentage point higher potential migration rate for college and non-college educated (relative to an average of 0.49 and 0.71 percentage points for non-college educated and college educated, respectively). Do networks also increase actual migration once we control for potential migration? The estimates in column 3 of Tables 7 and 8 show that their impact on actual migration after controlling for the potential rate is smaller and not always significant. For non-college educated, the impact corresponds to a 0.03 percent increase for each standard deviation. Considering that the direct effect of networks on potential rates was around 0.9 (for a standard deviation increase) and that potential rates translate into actual rates with a coefficient of 0.04 for non-college educated, the effect of networks through potential migration $(0.9 \times 0.04=0.036)$ is as large as the direct effect on creating opportunities for less educated migrants. For college educated, the effect of their network on migration opportunities was not significant, as they probably become aware of them more easily through other (work or professional) channels. Still the impact on potential migrants was very large.

Columns 4 and 5 introduce the free labor mobility and visa waiver dummies. In column 4, we include the policy dummies for all those pairs of countries with bilateral agreements as of 2000, the beginning of the period we consider. Free labor mobility could in principle significantly increase actual migration by creating migration opportunities that were previously denied. Similarly, the presence of a visa waiver agreement can make a country more accessible to foreign travelers, especially from less developed countries.

Neither policies automatically imply migration opportunities, jobs or demand for migrants. The estimates show that both free mobility and visa waiver agreements increased actual migration rates for non-college educated by around 0.01 percent, which is a very modest amount. For college educated, the effects were not significant. This is a first sign that it may take more than simple bilateral mobility agreements to generate migration opportunities. One may also argue that countries agreeing to mutual free labor mobility or visa waiving are those with similar characteristics (Neumayer, 
2006), which would result in lower gains for migrants. Hence, a free labor market or a visa waiving agreement does not per se need to stimulate mobility across those countries. Finally, one might reason that the 2000s formed a period of slow growth in Europe (with a deep recession and financial crisis towards the end of the decade), which may have discouraged migration altogether. In general, once geographical and cultural proximity are controlled for (distance, border, language and legal origin dummies), the free labor mobility dummy becomes weakly significant, even for non-college educated.

Thus, our results suggest that economic growth, more than free labor migration policies is a proximate determinant of actual migration rates of non-college educated, once we control for potential rates. Overall, we find that free labor mobility policies and the visa waiver policies did not have a strong impact on migration, on creating actual migration opportunities over the 2000-2010 period, or on increasing the pool of potential migrants.

In column 6 of Tables 7 and 8 we calculate potential migration including only those individuals who revealed a preference for permanent migration. As net migration rates capture long-run permanent changes, they might be expected to be most affected by potentially permanent migrants. In line with this intuition, we find that the impact of permanent potential migrants on actual net migration is somewhat stronger than that of total potential migration (with a coefficient of 0.058 for non-college educated and 0.17 for college educated). The effect of the remaining variables remains largely unchanged. The intentions to migrate permanently and their distribution across country couples are in fact very strongly correlated to the overall intentions to migrate $^{[10]}$.

\section{Interactions with potential migration rates}

Economic growth in the destination countries encourages migration flows by creating new opportunities. Was this effect stronger for origin countries that had a larger potential migration rate to that destination? Similarly, did free migration policies and networks interact with the pool of potential

migrants from specific origins so that their effect was not linear but larger for countries with more potential migrants? The linear form of equation (4) is a simplification. Including some interaction terms would allow for a different marginal effect of policies and economic opportunities depending on the size of the potential migrant pool.

In Table 10 we interact the "potential migration variable" with the growth 
of GDP per person at destination (columns 1 and 3), or with the free migration and visa waiver dummies (columns 2 and 4 ) or with the size of the network of household members abroad (specifications 3 and 6). The interaction variables are divided by their standard deviation so that the coefficients are easier to interpret. The table shows the impact on non-college educated (columns 1-3) and college educated (columns 4-6) migration rates. The only interaction effect that turns out to be significant is that of GDP per capita growth and potential rates for the non-college educated (as well as that of the visa waiver dummy with potential rates for college educated, though only marginally significant and negative). In fact, an acceleration of GDP growth by 1.5 percent per year in the US relative to an acceleration by 1.5 percent per year in Spain would generate an interaction with potential migration from India of about 15 percent in the US and almost zero in Spain, which is about one standard deviation of the interaction. The actual migration rate of less educated from India would thus be 0.027 percentage points larger to the US than to Spain as a consequence of their common higher growth rate but different migration potentials. This also implies, for instance, that growth in the US would attract a much larger number of migrants from Mexico than a similar growth rate in Europe would. Faster growth in Germany would, vice-versa, produce a larger effect on emigration for less educated Turkish nationals than would be produced by growth in any other country (as the potential migration rate for less educated from Turkey to Germany was larger than 3 percent compared to a potential rate of less than 1 percent towards any other country).

\section{$<<$ Table 10 about here $>>$}

Interestingly, economic growth produced opportunities for actual migration and attracted less educated more strongly from countries with larger potential migration rates. Less educated actual migration appears to be higher for countries with a visa waiver agreement, yet the interaction term with potential migration appears insignificant. Free mobility of labor laws, on the other hand, did not affect the actual migration rates (for college nor for non-college educated) nor did they affect them differentially depending on migration potentials. The strongest results from the analysis of actual migration is the difference between college and non-college educated in the rate at which potential migrants turn into actual migrants. This rate seems to be somewhat affected by economic growth at destination but does not seem to 
be systematically influenced by free mobility policies or by the presence of networks.

\section{Differences between rich and poor countries of origin}

In Table 11 we analyze whether the relationship between potential migrants, migration opportunities and actual migrants is different when considering only poor countries of origin. We select countries of origin in Asia, Latin America and Africa (omitting therefore the rich continents of the world) and estimate specifications similar to the basic ones in Tables 7, 8 and 9 . The basic specification (columns 1 and 4 ) shows that, as found for the total sample, potential emigration rates affect actual ones and this effect is much stronger for college educated (coefficient of 0.22 ) than for non-college educated (coefficient of 0.05). The estimated values are close to those estimated for the whole sample and possibly somewhat larger, especially for college educated. The sensitivity of actual migration rates to growth rates at destination, controlling for potential rates is also roughly as before, and 3 to 4 times larger for college educated than for non-college educated. These results suggest that, for less developed countries, there is no particular intensity of selection of potential migrants into actual ones.

Furthermore, we see that income levels and employment rates at destination (columns 2 and 5) do not additionally affect actual migration rates aside from their impact on potential rates. Moreover, higher growth rates at destination stimulate actual migration and they have a stronger effect (interaction) on countries with a larger migration potential (columns 3 and 6). Finally, the visa waiver policies have a minor positive effect on migration rates of non-college educated. The similarity of the coefficients estimated in Table 11 with those for the whole sample in Tables 7 and 8 implies that migrants from poorer countries of origin, especially the less educated ones, are not different from migrants from richer countries in their response to incentives. Similarly, potential college educated migrants from low-income countries of origin have a much larger probability of becoming actual migrants relative to the less educated. Hence, immigration opportunities in the considered destination countries (affected by the economy, policy and other factors) do not seem to "discriminate" based on the origin of immigrants, but are certainly more accessible for individuals with a college education. Alternatively, more educated people might simply be better in realizing migration potentials by searching for the right opportunities. Understanding better what determines 
the difference in transforming potential migrants into actual migrants between college and non-college educated is a very important step to predict the future of migration flows in the world. The data and simple procedures used in this paper are a starting point for this analysis.

$$
<<\text { Table } 11 \text { about here }>>
$$

\section{CONCLUSIONS}

Potential migrants are those people who aspire to migrate and look for migration opportunities. Actual migrants are those among potential migrants, that found and took advantage of a migration opportunity, and moved to a foreign country. We first identify the pool of potential migrants and the success of that pool in becoming actual migrants, using original data on the desire (willingness) to migrate and effective net migration from 138 origin countries to 30 major destinations over the 2000-2010 period. We then empirically study the determinants of potential migration and its realization rate, highlighting the role of economic factors, networks and migration policies.

Interestingly, our results are consistent with rational behavior-the income level and employment probability at destination, as well as the presence of networks of co-nationals, are crucial determinants of the pool of potential migrants. However, in turning potential migrants into actual migrants, the factors that matter most are having a college education and the growth perspectives in the receiving country. According to our estimates one out of five college educated potential migrants became an actual migrant (within the considered decade), while only one in twenty potential migrants among non-college educated finally migrated.

The migration literature has established the value of analytically separating migration aspirations from opportunities to migrate (Carling, 2002). The economic literature, on the other hand, has mainly focused on actual migration rates without differentiating non-migrants by whether or not they are searching for migration opportunities (Grogger and Hanson, 2011). This study connects the two-step approach to migration with economic modeling. We emphasize the most interesting and selective step in the process: from potential to actual migrants. This is a passage that is only understood if we take a two-step approach. We hope that through the use of uniquely large-scale 
data, additional theoretical sources, and new methodological frameworks, we contribute to further strengthening the two-step approach to international migration.

\section{Notes}

${ }^{[1]}$ In the two dataset used in this paper, the definition of college educated is slightly different. In the data on actual migration college educated are defined as described here. In the Gallup poll only individuals with a college degree are defined as college educated (we do not have information on individuals who attended college without graduating). Hence we use the desired migration rates for college graduates and apply them to to the population of all college educated.

${ }^{[2]}$ In the Appendix, we describe in greater detail the methodology and the original data used to construct actual and desired migration rates. We also show in Table A3 the summary statistics for all 138 countries of origin.

${ }^{[3]}$ See Smith and Swanson (1998) and Rogers (1990) for a discussion of the pros and cons in the use of net and gross migration rates.

${ }^{[4]}$ It could be argued that individuals are willing to migrate to many different destinations and decide which country to move to only once an opportunity arises. In this case the only meaningful distinction would be between willing and non-willing, making the bilateral preferences irrelevant. We will describe and analyze overall emigration rates (rather than bilateral) as well. Their responses to economic and network variables are similar to the response of bilateral rates implying that we are not distorting the choice too much by analyzing potential migration as bilateral preferences.

${ }^{[5]}$ A Random Utility Maximization model with (i) individuals with heterogeneous preferences, maximizing utility that depends on the same arguments as function $f$ above, and (ii) errors following a Gumbel distribution, would produce a linear relation between the logarithm of $p_{o, d}^{s}$, the odds-ratio of migrating or not, and the arguments of the function $f$. This simpler form can be considered a linear approximation of the former.

${ }^{[6]}$ The variable is constructed as the share of the resident population answering yes to the question: "Have any members of your household gone to live in a foreign country permanently or temporarily in the past five years?".

${ }^{[7]}$ The total number of observations for actual migration from 143 origins into 30 destinations is 5,673. However, we are missing desired migration data for some countries of origin (mainly small developing countries) that therefore are dropped, leaving us with 4,247 observations. Eliminating observations five times larger than the standard deviation, we are left with 4,162 valid observations.

${ }^{[8]}$ The remaining summary statistics for the other control and explanatory variables are reported in Table A1 in the appendix.

${ }^{[9]}$ There is also a large literature analyzing the impact of these bilateral factors on trade. See e.g. Ortega and Peri (2014). 
${ }^{[10]}$ Further checks and regressions that we performed and do not report convinced us that potential migration rates (both bilateral and aggregate by origin) are very highly correlated whether calculated using total migration or only permanent migration intensions. Hence we used total potential migration throughout the paper. 


\section{References}

Autor, D., Katz, L. and Kearney, M. (2008), "Trends in U.S. wage inequality: Revising the revisionists", Review of Economics and Statistics, Vol. 90 (May), pp. 30-23.

Artuç, E., Docquier, F., Özden, Ç. and Parsons, C. (forthcoming), "A global assessment of human capital mobility: The role of non-OECD destinations" World Development.

Bahna, M. (2008), "Predictions of migration from the new member states after their accession into the European Union: Successes and failures", International Migration Review, Vol. 42 No. 4, pp. 844-860.

Bauer, T. and Zimmermann, K.F. (1997), "Network migration of ethnic Germans", International Migration Review, Vol. 31 No. 1, pp. 143-149.

Becerra, D. (2012), "The Impact of Anti-Immigration Policies and Perceived Discrimination in the United States on Migration Intentions among Mexican Adolescents." International Migration 50(4):20-32.

Becerra, D., Gurrola, M., Ayón, C., Androff, D., Krysik, J., Gerdes, K., Moya-Salas, L. and Segal, E. (2010), "Poverty and other factors affecting migration intentions among adolescents in Mexico", Journal of Poverty, Vol. 14 No. 1, pp. 1-16.

Beine, M., Bertoli, S. and Fernández-Huertas Moraga, J. (forthcoming), "A practitioners' guide to gravity models of international migration", World Economy.

Beine, M., Docquier, F. and Özden, Ç. (2011), "Diasporas", Journal of Development Economics, Vol. 95 No. 1, pp. 30-41.

Bertoli, S. and Fernández-Huertas Moraga, J. (2013), "Multilateral resistance to migration", Journal of Development Economics, Vol. 102, pp. 79-100.

Borjas, G.J. (1987), "Self-selection and the earnings of immigrants" American Economic Review, Vol. 77 No. 4, pp. 531-553.

Brücker, H., Capuano, S. and Marfouk, A. (2013), "Education, gender and international migration: Insights from a panel-dataset 1980-2010", mimeo. 
Carling, J. (2002), "Migration in the age of involuntary immobility: Theoretical reflections and Cape Verdean experiences", Journal of Ethnic and Migration Studies, Vol. 28 No. 1, pp. 5-42.

Chassamboulli, A. and Peri, G. (2014), "The labor market effects of reducing undocumented immigrants", NBER Working Paper 19932, NBER, Cambridge, Mass., February 2014.

Clark, X., Hatton, T.J. and Williamson, J.G. (2007), "Explaining U.S. immigration 1971-1998", Review of Economics and Statistics, Vol. 89 No. 2, pp. 359-373.

Creighton, M.J. (2013), "The role of aspirations in domestic and international migration", Social Science Journal, Vol. 50 No. 1, 79-88.

Czaika, M. and Vothknecht, M. (2014), "Migration and aspirations - Are migrants trapped on a hedonic treadmill?", IZA Journal of Migration Vol. 3 No. 1.

Docquier, F., Özden, Ç. and Peri, G. (2014), "The labour market effects of immigration and emigration in OECD countries", The Economic Journal, doi: $10.1111 /$ ecoj.12077.

De Jong, G.F. (2000), "Expectations, gender, and norms in migration decision-making", Population Studies, Vol. 54 No. 3, pp. 307-319.

De Jong, G.F., Richter, K. and Isarabhakdi, P. (1996), "Gender, values, and intentions to move in rural Thailand", International Migration Review, Vol. 30 No. 3, pp. 748-770.

Fawcett, J.T. (1989), "Networks, linkages, and migration systems", International Migration Review Vol. 23 No. 3, pp. 671-680.

Gallup (2012), "Worldwide Research Methodology and Codebook", Washington D.C.

Goldin, C. and Katz., L.F. (2008), The Race between Education and Technology, Harvard University Press, Cambridge, Mass.

Grogger, J. and Hanson, G.H. (2011), "Income maximization and the selection and sorting of international migrants", Journal of Development Economics, Vol. 95, pp. 42-57. 
Gregg, P. and Petrongolo, B. (2005), "Stock-flow matching and the performance of the labor market", European Economic Review, Vol. 49 No. 8, pp. 1987-2011.

Hagen-Zanker, J., Siegel, M. and de Neubourg, C. (2009), "Strings attached: The impediments to migration in Albania and Moldova", Southeast European and Black Sea Studies, Vol. 9 No. 4, pp. 459-479.

Hanson, G.H. and McIntosh, G. (2010), "The great Mexican emigration", The Review of Economics and Statistics, Vol. 92 No. 4, pp. 798-810.

Hatton, T.J. (2005), "Explaining trends in UK immigration", Journal of Population Economics, Vol. 18 No. 4, pp. 719-740.

Hatton, T.J. and Williamson, J.G. (2005), "What fundamentals drive world migration?", in Borjas, G. and Crisp, J. (Eds.), Poverty, International Migration and Asylum, Palgrave-Macmillan, UK, Hampshire, pp. 15-38.

Helbling, M. and Vink, M.P. (2013), "The use and misuse of policy indices in the domain of citizenship and integration", Comparative European Politics, Vol. 11 No. 5, pp. 551-554.

Hooghe, M., Trappers, A., Meuleman, B. and Reeskens, T. (2008), "Migration to European countries: A structural explanation of patterns, 1980-2004", International Migration Review, Vol. 42, pp. 476-504.

Esipova, N., Ray, J. and Pugliese, A. (2011), "Gallup World Poll: The many faces of global migration", IOM Migration Research Series 43, International Organization for Migration, Switzerland, Geneva.

Jónsson, G. (2008), "Migration aspirations and immobility in a Malian Soninke village", IMI Working Paper 10-2008, International Migration Institute, UK, Oxford.

Karemera, D., Iwuagwu Oguledo, V. and Davis, B. (2000), "A gravity model analysis of international migration to North America", Applied Economics, Vol. 32, pp. 1745-1755.

Manchin, M., Manchin, R. and Orazbayev, S. (2014), "Desire to migrate internationally and locally and the importance of satisfaction with amenities", paper presented at the FIW-wiiw Seminars in International Economics, 10 April 2014, Austria, Vienna. 
Mayda, A.M. (2010), "International migrations: A panel data analysis of the determinants of bilateral flows", Journal of Population Economics, Vol. 23 No. 4, pp. 1249-1274.

Mayer and Zignago (2011). "Notes on CEPII's distances measures (GeoDist)", CEPII Working Paper 2011-25.

McFadden, D. (1974), "Conditional Logit Analysis of Qualitative Choice Behavior", in Zarembka, P. (Ed.), Frontiers in Econometrics, Academic Press, US, New York, pp. 105-142.

Moretti, E. (2012), The New Geography of Jobs, Houghton Mifflin Harcourt Publishing, New York.

Neumayer, E. (2006), Unequal Access to Foreign Spaces: How States Use Visa Restrictions to Regulate Mobility in a Globalised World, Transactions of the British Institute of Geographers Vol. 31 No. 1, pp. 72-84.

Ortega, J. (2000), "Pareto-improving immigration in an economy with equilibrium employment", Economic Journal, Vol. 110, pp. 92-112.

Ortega, F. and Peri, G. (2013), "The role of income and immigration policies on international migrations", Migration Studies, Vol. 1 No. 1, pp. 47-74.

Ortega, F. and Peri, G. (2014), "Openness and income: The roles of trade and migration", Journal of International Economics, Vol. 92 No. 2, pp. 231251.

Papapanagos, H. and Sanfey, P. (2001), "Intention to emigrate in transition countries: The case of Albania", Journal of Population Economics, Vol. 14 No. 3, pp. 491-504.

Paul, A.M. (2011), "Stepwise international migration. A multistage migration pattern for the aspiring migrant", American Journal of Sociology, Vol. 116 No. 6, pp. 1842-1886.

Pedersen, P.J., Pytlikova, M. and Smith, N. (2008), "Selection and network effects: Migration flows into OECD countries, 1990-2000", European Economic Review, Vol. 52 No. 7, pp. 1160-1186.

Petrongolo, B. and Pissarides, C. (2006), "Scale effects in markets with search", Economic Journal, Vol. 116 No. 508, pp. 21-44. 
Pissarides, C.A. (2000), Equilibrium Unemployment Theory, MIT Press, Cambridge, Mass.

Pissarides, C.A. and Petrongolo, B. (2001), "Looking into the black box: A survey of the matching function", Journal of Economic Literature, Vol. 39 No. 2, pp. 390-431.

Putterman, L. and Weil, D.N. (2010), "Post-1500 population flows and the long-run determinants of economic growth and inequality", The Quarterly Journal of Economics, Vol. 125 No. 4, pp. 1627-1682.

Rogers, A. (1990), "Requiem for the net migrant", Geographical Analysis, Vol. 22 No. 4, pp. 284-300.

Roy, A.D. (1951), "Some thoughts on the distribution of earnings", Oxford Economic Papers, Vol. 3, pp. 135-146.

Ruyssen, I., Everaert, G. and Rayp, G. (2014), "Determinants and dynamics of migration to OECD countries in a three-dimensional panel framework", Empirical Economics, Vol. 46 No. 1, pp. 175-197.

Sjaastad, L.A. (1962), "The costs and returns of human migration", Journal of Political Economy, Vol. 70 No. 5, pp. 80-93.

Smith, S.K. and Swanson, D.A. (1998), "In defense of the net migrant", Journal of Economic and Social Measurement, Vol. 24 No. 3, pp. 249-264.

Spolaore, E. and Wacziarg, R. (2009), "The diffusion of development", Quarterly Journal of Economics, Vol. 124 No. 2, pp. 469-529.

United Nations, Department of Economic and Social Affairs (2013), Trends in International Migrant Stock: The 2013 revision - Migrants by Destination and Origin, United Nations database, POP/DB/MIG/Stock/Rev.2013/Origin.

van Dalen, H.P., Groenewold, G. and Fokkema, T. (2005a), "The effect of remittances on emigration intentions in Egypt, Morocco, and Turkey", Population Studies, Vol. 59 No. 3, pp. 375-392.

van Dalen, H.P., Groenewold, G. and Schoorl, J.J. (2005b), "Out of Africa: What drives the pressure to emigrate?", Journal of Population Economics, Vol. 18 No. 4, pp. 741-778. 
Wissink, M., Düvell, F. and van Eerdewijk, A. (2013), "Dynamic migration intentions and the impact of socio-institutional environments: A transit migration hub in Turkey", Journal of Ethnic and Migration Studies, Vol. 39 No. 7, pp. 1087-1105.

Wood, C.H., Gibson, C.L., Ribeiro, L. and Hamsho-Diaz, P. (2010), "Crime victimization in Latin America and intentions to migrate to the United States", International Migration Review, Vol. 44 No. 1, pp. 3-24.

Yang, X. (2000), "Determinants of migration intentions in Hubei Province, China: Individual versus family migration", Environment and Planning, Vol. 32 No. 5, pp. 769-787. 


\section{Data Appendix}

We construct bilateral data on actual migration rates $\left(m_{o, d}^{s}\right)$ and willingness (or desire) to emigrate $\left(w_{o, d}^{s}\right)$ for college educated and less educated individuals $(s=H, L)$, for 138 countries of origin $(o=1, \ldots, 138)$ and 30 countries of destination $(d=1, \ldots, 30)$ for the period 2000-2010. These rates are expressed as percent of the non-migrant, native population aged 25 and over in country $o$ in the year 2000. Potential migration rates are simply defined as the sum of actual and desired migration: $p_{o, d}^{s} \equiv m_{o, d}^{s}+w_{o, d}^{s}$. This appendix describes our data sources and methodology.

\section{Actual migration}

Our starting point is the recent IAB database described in Brücker et al. (2013). They document the bilateral migration stocks $\left(S t o c k M_{o, d}^{s, t}\right)$ of individuals aged 25 and over by education level, from 195 origin countries to 20 destination countries, from 1980 to 2010 in 5 -year intervals $(t=1980, \ldots, 2010)$. We only use the 2000 and 2010 waves and proxy net migration flows by taking the difference between the migrant stock in 2010 and 2000: $M_{o, d}^{s}=$ Stock $M_{o, d}^{s, 2010}-S t o c k M_{o, d}^{s, 2000}$ (as in Beine et al., 2011; or Docquier et al., 2014).

The IAB database relies on census and register data collected from 20 major OECD destination countries. As for the year 2000, they obtained census or register data from all countries. As far as 2010 is concerned, they obtained census data for 8 countries (Denmark, France, Finland, Germany, the Netherlands, Norway, Sweden and the US); 2010 was extrapolated on the basis of 2005-06 census data in 4 other cases (Australia, Canada, Ireland, New Zealand). In the other 8 cases (Austria, Chile, Greece, Luxembourg, Portugal, Spain, Switzerland and UK), they imputed 2010 stocks on the basis of the 1990-2000 growth rates.

To cover the most important receiving countries of the world (many of which are reported as preferred destinations of would-be migrants), we extend the IAB database and construct estimates of net migration flows to 10 additional destination countries (Belgium, Israel, Italy, Japan, Mexico, Poland, Russia, Saudi Arabia, South Africa and United Arab Emirates). For these countries, bilateral migration data of individuals aged 25 and over are provided for the year 2000 and by education level in Artuç et al. (forthcoming). We combine them with the United Nations database on bilateral migrant 
stocks from 1990 to 2010 without education breakdown and the 25-years-old threshold. Specifically, we multiply the 2000 bilateral stocks of Artuç et al. by the 2000-2010 bilateral growth factors of the United Nations. This simply means that we assume the growth rate of total bilateral migrant stocks to be identical to that of the bilateral stock of migrants aged 25 and over. We also assume there are 10 percentage points more college educated in the 2000-2010 net migration flow than in the 2000 migration bilateral stock, an assumption in line with the IAB database.

The database of Artuç et al. also documents the size and structure of the non-migrant population in each origin country in $2000, N_{o}^{s} \equiv S t o c k M_{o o}^{s, 2000}$. Actual migration rates during the period 2000-2010 are thus defined as $m_{o, d}^{s}=$ $M_{o, d}^{s} / N_{o}^{s}$.

\section{Willingness to emigrate}

The Gallup World Polls identify individuals expressing a desire to emigrate permanently or temporarily to another country. Individual data are available on a yearly basis from 2007 to 2013: we aggregate the seven waves to compute desired emigration rates around the year 2010. This allows us to limit the number of missing cells and increase the accuracy of our estimates. Adding these desired migrants in 2010 to the actual net migration flows will give the potential net migration flows between 2000 and 2010 .

A typical Gallup survey interviews about a 1,000 randomly selected individuals within each country. In some large countries such as China, India and Russia as well as in major cities or areas of special interest, over-samples are collected resulting in larger total numbers of respondents. The data are collected through telephone surveys in countries where the telephone coverage represents at least 80 percent of the population. In Central and Eastern Europe, as well as in the developing world, including much of Latin America, the former Soviet Union countries, nearly all of Asia, the Middle East, and Africa, on the other hand, an area frame design is used for face-to-face interviewing. As such, the sampling frame represents the entire civilian, non-institutionalized population aged 15 and over covering the entire country including rural areas (with the exception of areas where the safety of the interviewing staff is threatened, scarcely populated islands in some countries, and areas that interviewers can reach only by foot, animal, or small boat). The survey covers 394,459 respondents, i.e. an average of 2,761 observations per country. In some cases, the number of respondents is however small. As 
a robustness check, we will only consider countries where the willingness to emigrate has been computed from at least 37 college-educated and 75 less educated respondents.

The Gallup survey documents individual characteristics (such as age and education) and includes two relevant questions on intentions to emigrate; these questions were asked in 138 countries: (Q1) Ideally, if you had the opportunity, would you like to move permanently or temporarily to another country, or would you prefer to continue living in this country? And (Q2) To which country would you like to move? In line with the actual migration data, we only consider respondents aged 25 and over, and distinguish between individuals with college education and the less educated. ${ }^{[11]}$ By 2013, the 138 countries represented about 98 percent of the worldwide population aged 25 and over.

The first step consists of computing the aggregate proportion of individuals who express a willingness to leave their country, whatever their preferred country of destination. We denote this proportion by $\widehat{w}_{o T}^{s}$ ( $T$ for all destinations) for individuals of education type $s$ living in country $o$. To compute desired emigration rates, we aggregate individual responses to Q1 and weigh each observation by the relevant Gallup sample weight. These weights are designed to compensate for the low coverage of certain groups (by gender, race, age, educational attainment, and region) in the whole population. Gallup assigns a weight to each respondent "so that the demographic characteristics of the total weighted sample of respondents match the latest estimates of the demographic characteristics of the adult population available" for the country (Gallup, 2012). The willingness to migrate is given by the weighted proportion of respondents who answered positively to Q1.

In the second step, we use responses to Q2 to disaggregate the number of desired migrants by country of destination. For each origin country $o$ and skill type $i$, bilateral desired migration rates $\left(\widehat{w}_{o, d}^{s}\right)$ are obtained by multiplying the total willingness to emigrate $\left(\widehat{w}_{o T}^{s}\right)$ by the proportion of respondents to Q2 who declared that country $d$ is their preferred destination $\left(\sigma_{o, d}^{s}\right)$. A few desired migrants did not mention a desired destination (i.e. did not respond to Q2) but this is rarely the case. Given the large response rates to Q2, we ignore those who did not respond to Q2 to compute the bilateral shares. Finally, a few respondents answered to Q2 and mentioned a preferred destination without responding to Q1; we considered that they responded "Yes" to Q1.

Given that we want our actual and desired emigration rates to be ex- 
pressed as percent of the non-migrant, native population aged 25 and over in the year 2000, we correct for the change in the native population between 2000 and 2010, and compute our index of willingness to emigrate as $w_{o, d}^{s}=\widehat{w}_{o, d}^{s} N_{o, 2010}^{s} / N_{o, 2000}^{s}$.

\section{Explanatory variables}

The definition and source of the variables used in the regressions are the following:

- The stock of people born in country o resident of country $d$ in 2000, in percent of the population of non-migrant natives in $o$ in $2000\left(N e t w_{o, d}\right)$. Source: See the actual migration section in the data appendix.

- The share of people aged 25 and older in and native to country $o$ who report to have a household member abroad times the share of people aged 25 and older in and native to country $o$ who report to have a household member in country $d$, merged over all available waves between 2007 and 2013 (alternative measure of $N e t w_{o, d}$ ). Source: Gallup's World Poll Database (see $w_{o, d}^{s}$ for more details on data collection). Specifically, the propensity to have a household member abroad is obtained by combining the following questions: "Have any members of your household gone to live in a foreign country permanently or temporarily in the past five years?" and "In which country does/did he/she live?". The intensity of the diaspora connection is thus calculated as the product of the propensity for natives of country $o$ to reply positively to the first question and the propensity that natives of country $o$ report country $o$ as a settlement country for their household members abroad, each time merging all survey waves between 2007 and 2013. Note that these propensities are obtained using sample weights so that the demographic characteristics of the total weighted sample of respondents match those of the adult population in the respective country in terms of gender, race, age, educational attainment and region (see Gallup, 2012). Again, we correct for the change in the native population between 2000 and 2010 in order to express the stock of people with household members abroad as a share of the non-migrant, native population aged 25 and over in country $o$ in the year 2000 . 
- Gross domestic product per capita in the destination country in purchasing power parities in 2005 international $\$$ (Chain series) in 2000 $\left(y_{d, 2000}\right)$. Source: Penn World Tables 7.0.

- Employment as percentage of the population aged 15 and over in the destination country $\left(e_{d, 2000}\right)$. Source: World Development Indicators and Total Economy Database.

- Growth in gross domestic product per capita in the destination country in purchasing power parities in 2005 international $\$$ (Chain series) between 2000 and $2010\left(g y_{d}^{00-10}\right)$. Source: Penn World Tables 7.0.

- Growth in employment as percentage of the population aged 15 and over in the destination country between 2000 and $2010\left(g e_{d}^{00-10}\right)$. Source: World Development Indicators and Total Economy Database.

- Size of the population aged $25+$ in the destination country in 2000 $\left(\ln P o p_{d}\right)$. Source: Brücker et al. (2013).

- Set of bilateral variables capturing geographical, cultural and genetic distance across countries $\left(\right.$ Dist. $\left._{\cdot, d}\right)$, including:

- Population-weighted distance in kilometers between $o$ and $d$ (taken in logs). Source: CEPII Dyadic Distance Database (Mayer and Zignago, 2011).

- Dummy for sharing a border. Source: CEPII Dyadic Distance Database.

- Dummy for sharing a common official primary language. Source: CEPII Dyadic Distance Database.

- Dummy for sharing a common colonial past. Source: CEPII Dyadic Distance Database.

- Dummy for sharing a common legal origin. Source: Ortega and Peri (2014).

- Dummy for sharing a common currency. Source: Ortega and Peri (2014).

- Number of landlocked countries in the country pair. Source: CEPII Dyadic Distance Database. 
- Religious proximity between $o$ and $d$, i.e. the probability that two individuals randomly selected from $o$ and $d$ share the same religion. Source: Own calculations based on CIA World Factbook data on country-specific religious adherence.

- Genetic distance between $o$ and $d$, i.e. the probability that two alleles (a particular form taken by a gene) at a given locus selected at random from two populations are different (proxy for time since isolation). Source: Spoalore and Warcziag (2009), definitions p. $480-485$.

- Dummy for free labor mobility between $o$ and $d$ as of 2000 or 2010 (in Policy $_{o, d}$ ). The corridors which had free mobility in 2000 besides EU15EU15 involve the EU15 and Switzerland as well as Nordic countries, i.e. Denmark, Finland, Iceland, Norway and Sweden. In 2010, new corridors involve free mobility between (i) new accession countries that joined the EU between 2000 and 2010 (i.e. Bulgaria, Cyprus, Czech Rep, Estonia, Hungary, Latvia, Lithuania, Malta, Poland, Romania, Slovakia and Slovenia) and the EU15, Switzerland, Poland and Czech Republic. Source: Own calculations.

- Dummy for the presence of a visa waiving agreement between $o$ and $d$ in 2004 (in Policyo,d). This visa waiving dummy is based on country of citizenship rather than on country of birth. Source: Neumayer (2006) based on the November 2004 edition of the International Civil Aviation Association's Travel Information Manual. 
Table 1: Aggregate statistics on actual and desired migration rates (2000-2010)

As percentage points of the population in 2000

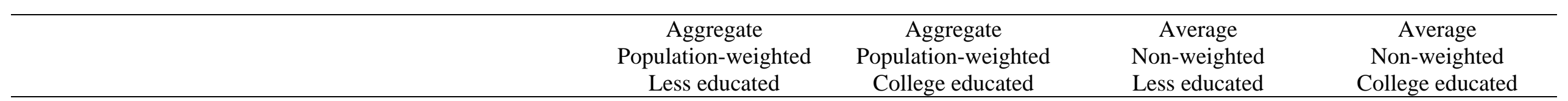

Actual and desired emigration rates, percentage points of the country-of-origin, native population

\begin{tabular}{|c|c|c|c|c|}
\hline Stock of emigrants/Native population 2000 & 1.8 & 5.8 & 6.4 & 34.9 \\
\hline $\begin{array}{l}\text { Actual emigration rate: Net emigrants } 2000-2010 \text { relative to } \\
\text { native population in the country of origin, } 2000\end{array}$ & 0.4 & 3.9 & 1.1 & 30.3 \\
\hline $\begin{array}{l}\text { Desired rate: Willing to Migrate } 2000-2010 \text {, still in the } \\
\text { country, relative to native population in the country of } \\
\text { origin, } 2000\end{array}$ & 8.5 & 16.2 & 14.2 & 21.4 \\
\hline
\end{tabular}

\section{Actual and desired immigration rates, percentage points of the country-of-destination, native population}

\begin{tabular}{|c|c|c|c|c|}
\hline Stock of immigrants/Native population 2000 & 9.4 & 10.9 & 20.9 & 30.0 \\
\hline $\begin{array}{l}\text { Actual immigration rate: Net immigrants } 2000-2010 \text { relative } \\
\text { to native population in the country of destination, } 2000\end{array}$ & 2.4 & 6.0 & 11.0 & 35.0 \\
\hline $\begin{array}{l}\text { Desired rate: Willing to Migrate } 2000-2010 \text {, still in the } \\
\text { country, relative to native population in the country of } \\
\text { destination, } 2000\end{array}$ & 42.0 & 26.0 & 87.0 & 93.0 \\
\hline
\end{tabular}

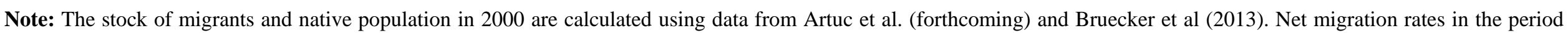

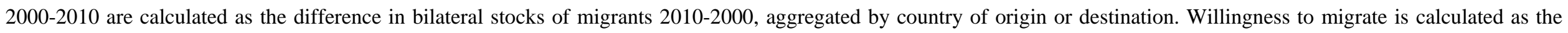

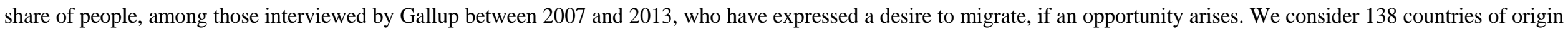
and 30 destinations. 
Table 2: Actual and desired immigration rates of college educated and the less educated by destination country

\begin{tabular}{|c|c|c|c|c|c|c|}
\hline Destination & $\begin{array}{c}\text { Net rates } 2000-2010 \\
\text { Less educated }\end{array}$ & $\begin{array}{c}\text { Net rates } 2000-2010 \\
\text { College educated }\end{array}$ & Skill Intensity & $\begin{array}{l}\text { Desired rates } \\
\text { Less educated }\end{array}$ & $\begin{array}{c}\text { Desired rates } \\
\text { College educated }\end{array}$ & Skill Intensity \\
\hline Australia & -0.6 & 33.5 & Skilled & 148.6 & 245.4 & Skilled \\
\hline Austria & 3.1 & 11.7 & Skilled & 37.7 & 72.9 & Skilled \\
\hline Belgium & 2.0 & 11.8 & Skilled & 24.1 & 16.4 & Unskilled \\
\hline Canada & -0.8 & 71.2 & Skilled & 142.3 & 240.7 & Skilled \\
\hline Chile & 16.7 & 20.8 & Skilled & 6.0 & 9.3 & Skilled \\
\hline Denmark & 2.9 & 8.6 & Skilled & 30.5 & 62.9 & Skilled \\
\hline Finland & 2.4 & 5.6 & Skilled & 15.1 & 78.3 & Skilled \\
\hline France & 1.8 & 7.3 & Skilled & 41.7 & 71.3 & Skilled \\
\hline Germany & 0.8 & 0.9 & Skilled & 26.0 & 44.2 & Skilled \\
\hline Greece & 7.1 & 23.1 & Skilled & 20.5 & 34.1 & Skilled \\
\hline Ireland & 6.1 & 30.4 & Skilled & 63.1 & 88.7 & Skilled \\
\hline Israel & -18.7 & 2.3 & Skilled & 35.8 & 38.0 & Skilled \\
\hline Italy & 1.3 & 7.5 & Skilled & 24.4 & 67.7 & Skilled \\
\hline Japan & 0.2 & 0.7 & Skilled & 12.8 & 9.3 & Unskilled \\
\hline Luxembourg & 10.5 & 23.6 & Skilled & 119.5 & 118.6 & Unskilled \\
\hline Mexico & 0.1 & 1.3 & Skilled & 3.8 & 8.5 & Skilled \\
\hline Netherlands & -4.3 & -0.9 & Skilled & 24.6 & 23.4 & Unskilled \\
\hline New Zealand & 9.1 & 8.7 & Unskilled & 212.4 & 154.6 & Unskilled \\
\hline Norway & 5.2 & 14.1 & Skilled & 48.0 & 78.5 & Skilled \\
\hline Poland & -0.9 & 1.0 & Skilled & 1.2 & 3.8 & Skilled \\
\hline Portugal & 6.7 & 21.4 & Skilled & 23.9 & 50.0 & Skilled \\
\hline Russian Federation & -2.7 & 1.0 & Skilled & 8.3 & 1.5 & Unskilled \\
\hline Saudi Arabia & 20.4 & 121.5 & Skilled & 300.0 & 173.4 & Unskilled \\
\hline South Africa & 2.8 & 18.4 & Skilled & 19.0 & 8.5 & Unskilled \\
\hline Spain & 10.6 & 20.0 & Skilled & 58.6 & 58.8 & Skilled \\
\hline Sweden & 4.7 & 15.4 & Skilled & 62.0 & 79.8 & Skilled \\
\hline Switzerland & 3.0 & 3.7 & Skilled & 119.9 & 295.5 & Skilled \\
\hline United Arab Emirates & 248.4 & 587.2 & Skilled & 937.7 & 622.4 & Unskilled \\
\hline United Kingdom & 0.9 & 26.3 & Skilled & 50.6 & 117.8 & Skilled \\
\hline United States & 6.3 & 3.9 & Unskilled & 92.8 & 12.9 & Unskilled \\
\hline Average & 11.1 & 35.8 & Skilled & 87.6 & 93.6 & Skilled \\
\hline
\end{tabular}


Figure 1

Potential and actual emigration rates of the less educated (138 countries of origin)

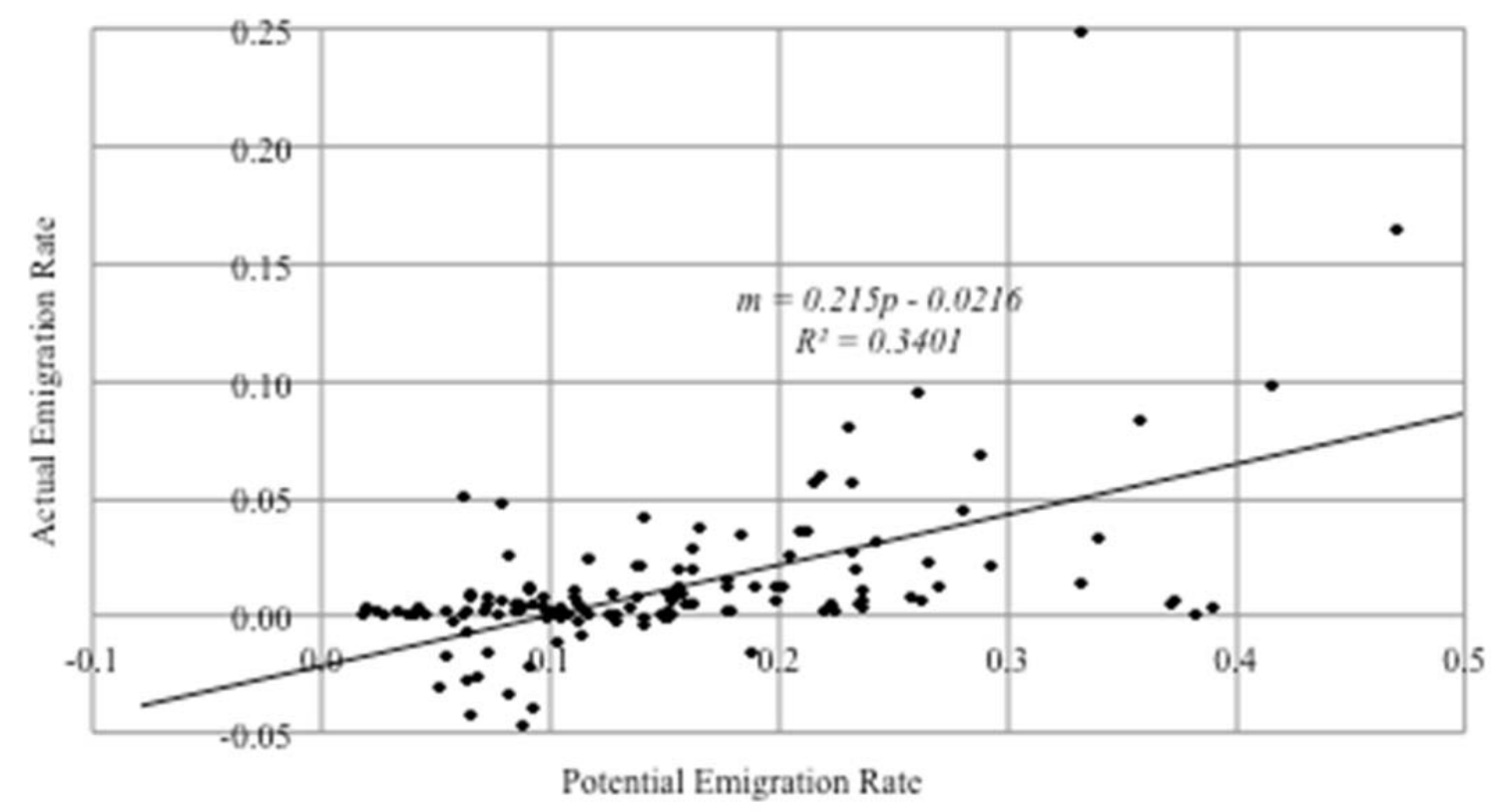

Notes: Actual and potential emigration rates are calculated as described in the text. They are aggregated by country of origin. Each point shows the total actual and potential migration rate from one origin to all destinations. 


\section{Figure 2}

Potential and actual emigration rates of college educated (138 countries of origin)

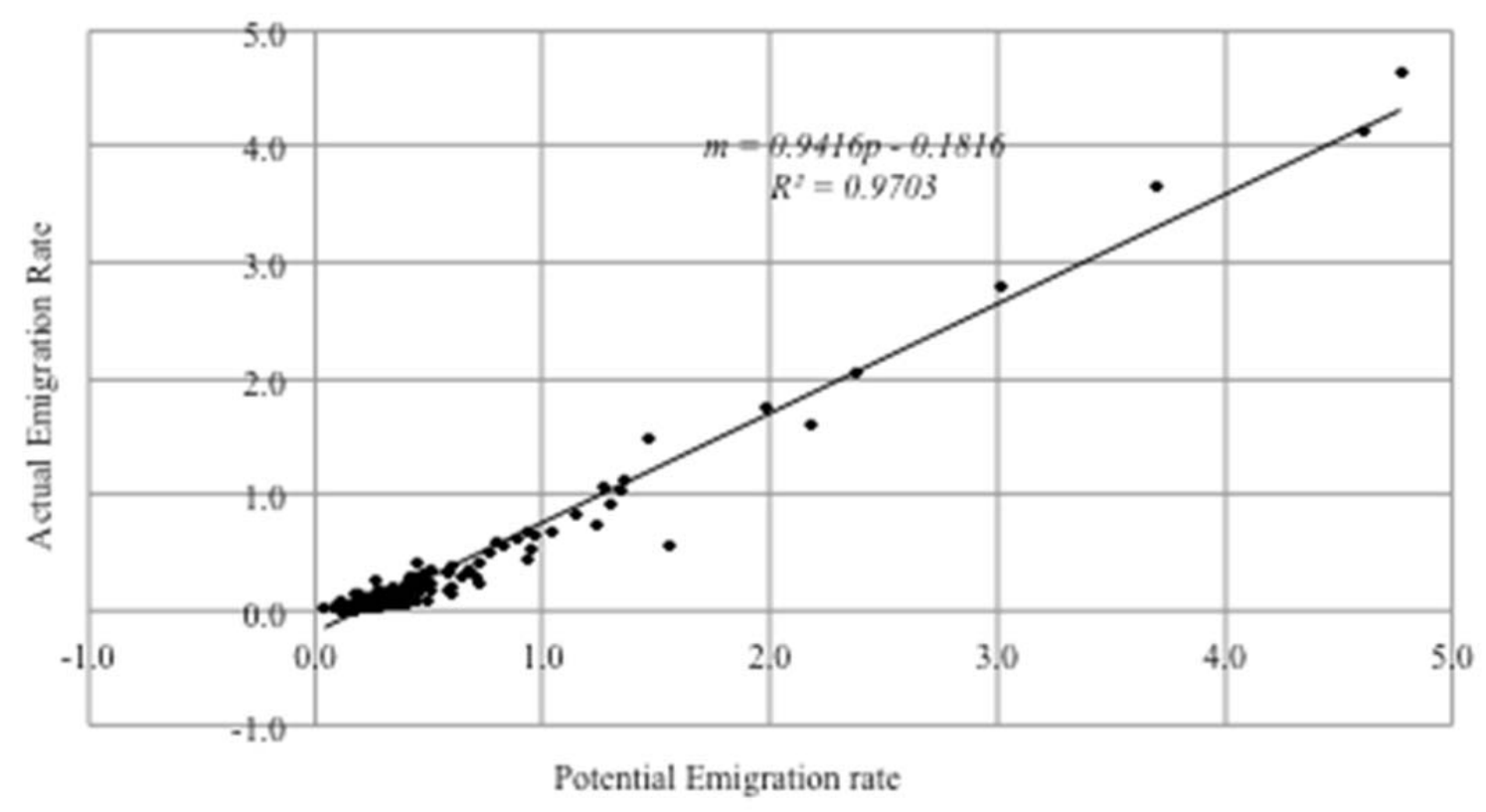

Notes: Actual and potential emigration rates are calculated as described in the text. They are aggregated by country of origin. Each point shows the total actual and potential migration rate from one origin to all destinations. 
Figure 3

Potential and actual immigration rates of the less educated (30 countries of destination)

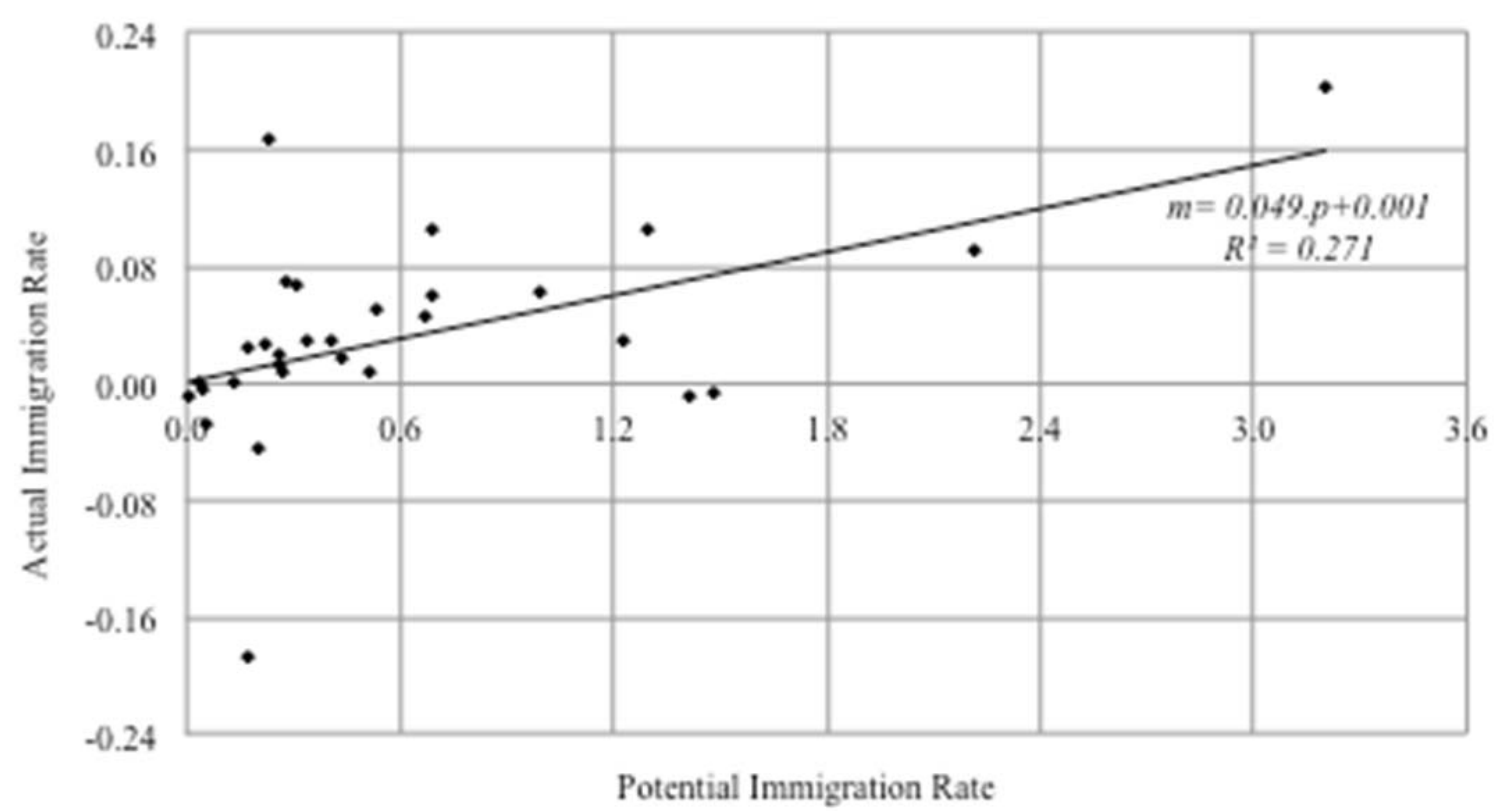

Notes: Actual and potential immigration rates are calculated by dividing the number of net migrants and potential migrants (2000-2010) by the native population in the destination country in 2000. They are aggregated by country of destination. Each point shows the total actual and potential migration rate from all origin countries to one destination. 
Figure 4

Potential and actual immigration rates of college educated (30 countries of destination)

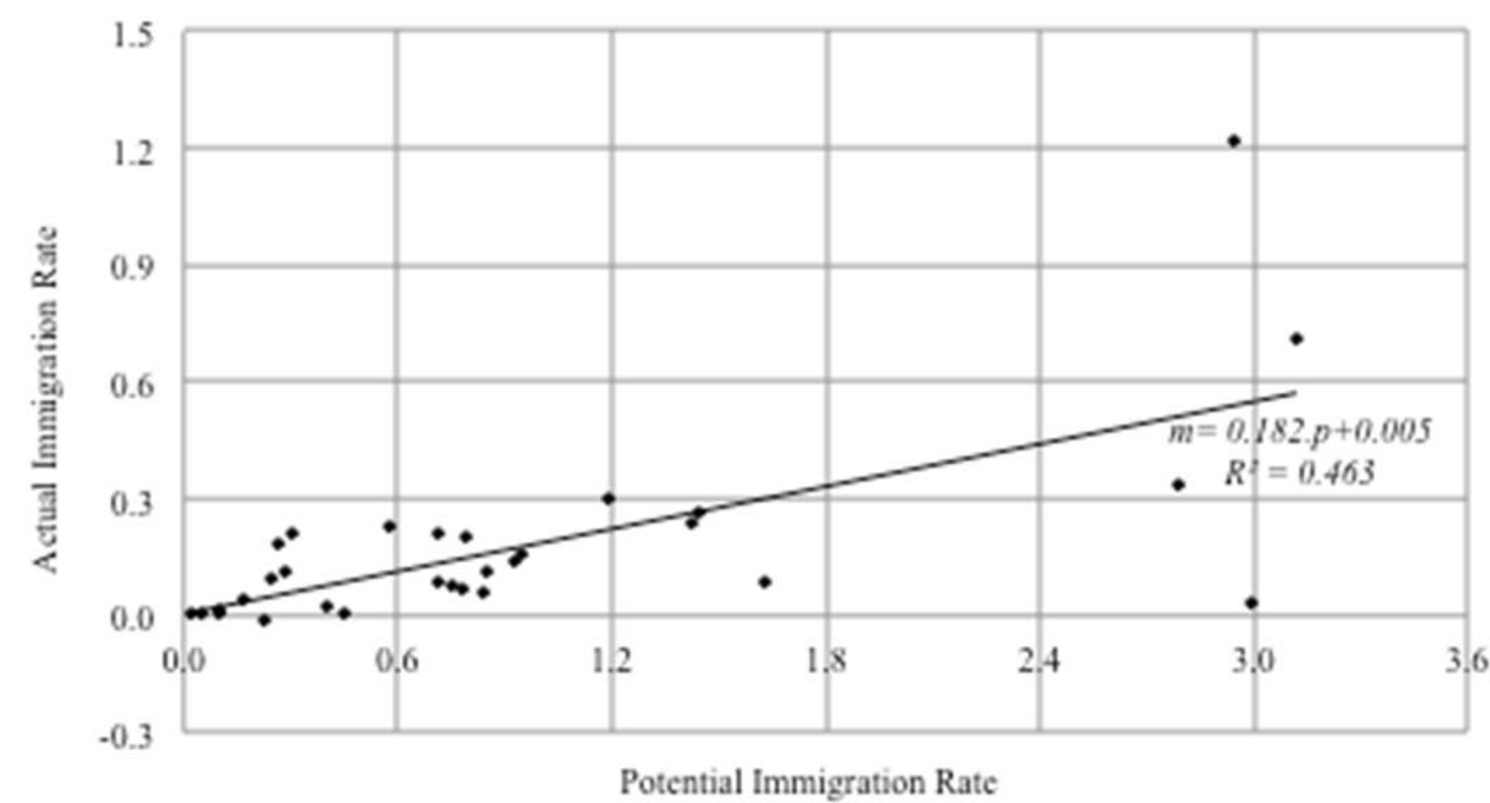

Notes: Actual and potential immigration rates are calculated by dividing the number of net migrants and potential migrants (2000-2010) by the native population in the destination country in 2000. They are aggregated by country of destination. Each point shows the total actual and potential migration rate from all origin countries to one destination. 
Table 3. Summary statistics: actual and potential migration rates, and measures of migration networks As percentage of the native population at origin in 2000

\begin{tabular}{|c|c|c|c|}
\hline & Observations & Mean & $\begin{array}{l}\text { Standard } \\
\text { deviation }\end{array}$ \\
\hline $\begin{array}{l}\text { Net emigration rate } 2000-2010 \text {, } \\
\text { Less educated }\end{array}$ & 5654 & 0.05 & 0.28 \\
\hline $\begin{array}{l}\text { Net emigration rate 2000-2010, } \\
\text { College educated }\end{array}$ & 4239 & 0.21 & 0.62 \\
\hline $\begin{array}{l}\text { Potential emigration rate } 2000-2010, \\
\text { Less educated }\end{array}$ & 4239 & 0.49 & 1.67 \\
\hline $\begin{array}{l}\text { Potential emigration rate } 2000-2010 \text {, } \\
\text { College educated }\end{array}$ & 4100 & 0.71 & 1.72 \\
\hline Stock of migrants relative to native population, 2000 & 5654 & 0.28 & 1.78 \\
\hline $\begin{array}{l}\text { Share of residents with at least one member of } \\
\text { household abroad in the last } 5 \text { years, non-college } \\
\text { educated }\end{array}$ & 3929 & 0.10 & 0.80 \\
\hline $\begin{array}{l}\text { Share of residents with at least one member of } \\
\text { household abroad in the last } 5 \text { years, college educated }\end{array}$ & 3929 & 0.07 & 0.30 \\
\hline
\end{tabular}

Notes: The unit of observation is a country of origin-country of destination pair. The average and standard deviation are calculated including all observations without weighting them. The definition of the actual and potential migration rates is given in the text. 
Table 4: Determinants of potential migration rates $(p \times 100)$ of non-college educated

138 sending countries to our 30 destination countries, 2000-2010

\begin{tabular}{|c|c|c|c|c|c|c|c|}
\hline Explanatory Variable: & $\begin{array}{c}\text { (1) } \\
\text { Basic, non- } \\
\text { negative rates }\end{array}$ & $\begin{array}{l}(2) \\
\text { All rates }\end{array}$ & $\begin{array}{c}\text { (3) } \\
\text { Basic } \\
\text { geography } \\
\text { and culture }\end{array}$ & $\begin{array}{l}\text { (4) } \\
\text { Extended } \\
\text { geography } \\
\text { and culture }\end{array}$ & $\begin{array}{c}\text { (5) } \\
\text { Including } \\
\text { contemporaneous } \\
\text { growth rate }\end{array}$ & $\begin{array}{c}\text { (6) } \\
\text { Policies }\end{array}$ & $\begin{array}{c}(7) \\
\text { Only migrants } \\
\text { from Asia- } \\
\text { Africa-Latin } \\
\text { America } \\
\end{array}$ \\
\hline $\begin{array}{l}\text { Stock migrants/ } \\
\text { population in } 2000\end{array}$ & $\begin{array}{c}0.83 * * * \\
(0.31)\end{array}$ & $\begin{array}{c}0.46 \\
(0.32) \\
\end{array}$ & $\begin{array}{l}0.77 * * \\
(0.31)\end{array}$ & $\begin{array}{l}0.73^{* *} \\
(0.31)\end{array}$ & $\begin{array}{l}0.77 * * \\
(0.31)\end{array}$ & $\begin{array}{l}0.77 * * \\
(0.31)\end{array}$ & $\begin{array}{l}0.95^{*} \\
(0.52) \\
\end{array}$ \\
\hline $\begin{array}{l}\text { Stock people with } \\
\text { household member } \\
\text { abroad/population }\end{array}$ & $\begin{array}{l}0.91 * * \\
(0.44)\end{array}$ & $\begin{array}{l}0.97 * * \\
(0.45)\end{array}$ & $\begin{array}{l}0.89 * * \\
(0.43)\end{array}$ & $\begin{array}{l}0.87 * * \\
(0.42)\end{array}$ & $\begin{array}{c}0.89 * * \\
(0.43)\end{array}$ & $\begin{array}{l}0.89 * * \\
(0.43)\end{array}$ & $\begin{array}{l}0.83^{*} \\
(0.44)\end{array}$ \\
\hline $\begin{array}{l}\text { Real GDP per person } \\
(1,000 \text { \$ PPP), } \\
\text { destination in } 2000\end{array}$ & $\begin{array}{l}0.02 * * * \\
(0.003)\end{array}$ & $\begin{array}{c}0.02 * * * \\
(0.03)\end{array}$ & $\begin{array}{l}0.02 * * * \\
(0.003)\end{array}$ & $\begin{array}{l}0.02 * * * \\
(0.003)\end{array}$ & $\begin{array}{l}0.02 * * * \\
(0.003)\end{array}$ & $\begin{array}{l}0.02 * * * \\
(0.003)\end{array}$ & $\begin{array}{l}0.02 * * \\
(0.004)\end{array}$ \\
\hline $\begin{array}{l}\text { Empl/Pop 15+, } \\
\text { destination in } 2000\end{array}$ & $\begin{array}{l}0.005 * * \\
(0.002)\end{array}$ & $\begin{array}{l}0.005 * * \\
(0.002)\end{array}$ & $\begin{array}{l}0.004^{* *} \\
(0.002)\end{array}$ & $\begin{array}{l}0.004^{* *} \\
(0.002)\end{array}$ & $\begin{array}{l}0.004^{* *} \\
(0.002)\end{array}$ & $\begin{array}{c}0.004^{* * *} \\
(0.002)\end{array}$ & $\begin{array}{c}0.007 * * * \\
(0.001)\end{array}$ \\
\hline $\begin{array}{l}\text { Free labor movement } \\
\text { dummy in } 2000\end{array}$ & & & & & & $\begin{array}{c}0.046 \\
(0.124) \\
\end{array}$ & \\
\hline Visa waiver dummy & & & & & & $\begin{array}{l}-0.016 \\
(0.085)\end{array}$ & \\
\hline $\begin{array}{l}\text { Growth of GDP per } \\
\text { person } 2000-2010\end{array}$ & & & & & $\begin{array}{l}-0.001 \\
(0.001)\end{array}$ & $\begin{array}{l}-0.001 \\
(0.001)\end{array}$ & $\begin{array}{l}-0.001 \\
(0.001)\end{array}$ \\
\hline Standard controls & $\begin{array}{l}\text { Origin FE, } \\
\ln \left(\mathrm{Pop}_{\mathrm{d}}\right)\end{array}$ & $\begin{array}{l}\text { Origin FE, } \\
\ln \left(\mathrm{Pop}_{\mathrm{d}}\right)\end{array}$ & $\begin{array}{c}\text { Origin FE, } \\
\ln \left(\mathrm{Pop}_{\mathrm{d}}\right)\end{array}$ & $\begin{array}{c}\text { Origin FE, } \\
\ln \left(\mathrm{Pop}_{\mathrm{d}}\right)\end{array}$ & $\begin{array}{c}\text { Origin FE, } \\
\ln \left(\mathrm{Pop}_{\mathrm{d}}\right)\end{array}$ & $\begin{array}{c}\text { Origin FE, } \\
\ln \left(\mathrm{Pop}_{\mathrm{d}}\right)\end{array}$ & $\begin{array}{c}\text { Origin FE, } \\
\ln \left(\mathrm{Pop}_{\mathrm{d}}\right)\end{array}$ \\
\hline $\begin{array}{l}\text { Geographical and } \\
\text { cultural controls }\end{array}$ & None & None & $\begin{array}{l}\text { ln(distance), } \\
\text { border, } \\
\text { common lang. }\end{array}$ & $\begin{array}{l}\text { ln(distance), } \\
\text { border, common } \\
\text { lang., colony, } \\
\text { legal origin, } \\
\text { currency, } \\
\text { landlocked, } \\
\text { religious prox., } \\
\text { genetic distance }\end{array}$ & $\begin{array}{l}\text { In(distance), } \\
\text { border, } \\
\text { common lang }\end{array}$ & $\begin{array}{l}\text { ln(distance), } \\
\text { border, } \\
\text { common lang }\end{array}$ & $\begin{array}{l}\text { ln(distance), } \\
\text { border, } \\
\text { common lang }\end{array}$ \\
\hline
\end{tabular}

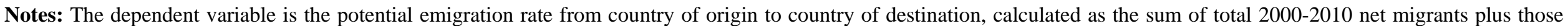

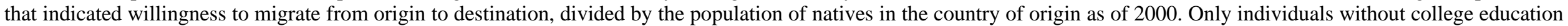

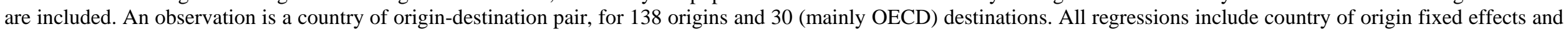

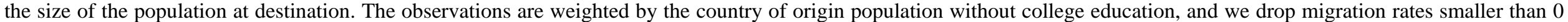
and larger than the $99^{\text {th }}$ percentile of the distribution. Standard errors are clustered by country of origin. ***,**,* imply significance at $1 \%$, $5 \%$ and $10 \%$ level. 
Table 5: Determinants of potential migration rates $(\mathrm{p} \times 100)$ of college educated

138 sending countries to our 30 destination countries, 2000-2010

\begin{tabular}{|c|c|c|c|c|c|c|c|}
\hline Explanatory Variable: & $\begin{array}{c}\text { (1) } \\
\text { Basic, non- } \\
\text { negative rates }\end{array}$ & $\begin{array}{l}(2) \\
\text { All rates }\end{array}$ & $\begin{array}{c}\text { (3) } \\
\text { Basic } \\
\text { geography } \\
\text { and culture }\end{array}$ & $\begin{array}{c}\text { (4) } \\
\text { Extended } \\
\text { geography } \\
\text { and culture }\end{array}$ & $\begin{array}{c}(5) \\
\text { Including } \\
\text { contemporaneous } \\
\text { growth rate }\end{array}$ & $\begin{array}{c}(6) \\
\text { Policies }\end{array}$ & $\begin{array}{c}\text { (7) } \\
\text { Only migrants } \\
\text { from Asia- } \\
\text { Africa-Latin } \\
\text { America }\end{array}$ \\
\hline $\begin{array}{l}\text { Stock migrants/ } \\
\text { population in } 2000\end{array}$ & $\begin{array}{c}1.03^{* * *} \\
(0.33) \\
\end{array}$ & $\begin{array}{c}0.94^{* * *} \\
(0.30) \\
\end{array}$ & $\begin{array}{c}0.98^{* * *} \\
(0.27) \\
\end{array}$ & $\begin{array}{c}0.80^{* * *} \\
(0.25) \\
\end{array}$ & $\begin{array}{c}0.99 * * * \\
(0.27) \\
\end{array}$ & $\begin{array}{c}0.964^{* * *} \\
(0.27)\end{array}$ & $\begin{array}{c}1.90 \\
(1.23) \\
\end{array}$ \\
\hline $\begin{array}{l}\text { Stock people with } \\
\text { household member } \\
\text { abroad /population }\end{array}$ & $\begin{array}{c}2.17 * * * \\
(0.35)\end{array}$ & $\begin{array}{c}2.17 * * * \\
(0.35)\end{array}$ & $\begin{array}{c}2.01 * * * \\
(0.32)\end{array}$ & $\begin{array}{c}2.01 * * * \\
(0.32)\end{array}$ & $\begin{array}{c}2.01 * * * \\
(0.32)\end{array}$ & $\begin{array}{c}1.9823 * * * \\
(0.332)\end{array}$ & $\begin{array}{c}1.70 * * * \\
(0.34)\end{array}$ \\
\hline $\begin{array}{l}\text { Real GDP per person } \\
(1,000 \text { \$ PPP), } \\
\text { destination in } 2000\end{array}$ & $\begin{array}{l}0.03^{* * *} \\
(0.002)\end{array}$ & $\begin{array}{l}0.03^{* * *} \\
(0.002)\end{array}$ & $\begin{array}{l}0.03 * * * \\
(0.003)\end{array}$ & $\begin{array}{l}0.03^{* * *} \\
(0.002)\end{array}$ & $\begin{array}{l}0.03^{* * *} \\
(0.003)\end{array}$ & $\begin{array}{c}0.035 * * * \\
(0.004)\end{array}$ & $\begin{array}{l}0.03^{* * *} \\
(0.006)\end{array}$ \\
\hline $\begin{array}{l}\text { Empl/Pop 15+, } \\
\text { destination in } 2000\end{array}$ & $\begin{array}{l}0.009^{*} \\
(0.005) \\
\end{array}$ & $\begin{array}{l}0.009^{*} \\
(0.005)\end{array}$ & $\begin{array}{l}0.01^{* *} \\
(0.005) \\
\end{array}$ & $\begin{array}{l}0.01 * * \\
(0.004) \\
\end{array}$ & $\begin{array}{l}0.01 * * \\
(0.04)\end{array}$ & $\begin{array}{l}0.011^{* *} \\
(0.005)\end{array}$ & $\begin{array}{l}0.02 * * * \\
(0.005)\end{array}$ \\
\hline $\begin{array}{l}\text { Free labor movement } \\
\text { dummy in } 2000\end{array}$ & & & & & & $\begin{array}{c}0.207 \\
(0.155)\end{array}$ & \\
\hline Visa waiver dummy & & & & & & $\begin{array}{c}0.112 \\
(0.078) \\
\end{array}$ & \\
\hline $\begin{array}{l}\text { Growth of GDP per } \\
\text { person } 2000-2010\end{array}$ & & & & & $\begin{array}{l}-0.001 \\
(0.001)\end{array}$ & $\begin{array}{l}-0.001 \\
(0.001)\end{array}$ & $\begin{array}{l}-0.001 \\
(0.001)\end{array}$ \\
\hline Standard controls & $\begin{array}{l}\text { Origin FE, } \\
\ln \left(\mathrm{Pop}_{\mathrm{d}}\right)\end{array}$ & $\begin{array}{l}\text { Origin FE, } \\
\ln \left(\mathrm{Pop}_{\mathrm{d}}\right)\end{array}$ & $\begin{array}{c}\text { Origin FE, } \\
\ln \left(\mathrm{Pop}_{\mathrm{d}}\right)\end{array}$ & $\begin{array}{c}\text { Origin FE, } \\
\ln \left(\mathrm{Pop}_{\mathrm{d}}\right)\end{array}$ & $\begin{array}{c}\text { Origin FE, } \\
\ln \left(\mathrm{Pop}_{\mathrm{d}}\right) \\
\end{array}$ & $\begin{array}{c}\text { Origin FE, } \\
\ln \left(\mathrm{Pop}_{\mathrm{d}}\right) \\
\end{array}$ & $\begin{array}{c}\text { Origin FE, } \\
\ln \left(\mathrm{Pop}_{\mathrm{d}}\right)\end{array}$ \\
\hline $\begin{array}{l}\text { Geographical and } \\
\text { cultural controls }\end{array}$ & None & None & $\begin{array}{l}\text { ln(distance), } \\
\text { border, } \\
\text { common lang. }\end{array}$ & $\begin{array}{l}\text { } \ln \text { (distance), } \\
\text { border, common } \\
\text { lang., colony, } \\
\text { legal origin, } \\
\text { currency, } \\
\text { landlocked, } \\
\text { religious prox., } \\
\text { genetic distance }\end{array}$ & $\begin{array}{l}\text { In(distance), } \\
\text { border, } \\
\text { common lang }\end{array}$ & $\begin{array}{l}\text { ln(distance), } \\
\text { border, } \\
\text { common lang }\end{array}$ & $\begin{array}{l}\text { In(distance), } \\
\text { border, } \\
\text { common lang }\end{array}$ \\
\hline
\end{tabular}

Notes: The dependent variable is the potential emigration rate from country of origin to country of destination, calculated as the sum of total $2000-2010$ net migrants plus those that indicated willingness to migrate from origin to destination, divided by the population of natives in the country of origin as of 2000. Only individuals with college education are included. An observation is a country of origin-destination pair, for 138 origins and 30 (mainly OECD) destinations. All regressions include country of origin fixed effects and the size of the population at destination. The observations are weighted by the country of origin population with college education, and we drop migration rates smaller than 0 and larger than the $99^{\text {th }}$ percentile of the distribution. Standard errors are clustered by country of origin. $* * *, * *, *$ imply significance at $1 \%, 5 \%$ and $10 \%$ level. 
Table 6: Determinants of potential migration rates, Robustness Checks

138 sending countries to our 30 destination countries, 2000-2010

\begin{tabular}{|c|c|c|c|c|c|c|}
\hline \multirow[b]{2}{*}{ Explanatory Variable: } & \multicolumn{3}{|c|}{ Less educated } & \multicolumn{3}{|c|}{ College educated } \\
\hline & $\begin{array}{c}(1) \\
\text { Including } \\
\text { destination } \\
\text { continent } \\
\text { dummies }\end{array}$ & $\begin{array}{c}\text { (2) } \\
\text { Only willing to } \\
\text { emigrate as } \\
\text { dependent } \\
\text { variable }\end{array}$ & $\begin{array}{c}\text { (3) } \\
\text { Only most } \\
\text { reliable data on } \\
\text { willingness to } \\
\text { emigrate }\end{array}$ & $\begin{array}{c}\text { (4) } \\
\text { Including } \\
\text { destination } \\
\text { continent } \\
\text { dummies }\end{array}$ & $\begin{array}{l}\text { (5) } \\
\text { Only willing to } \\
\text { emigrate as } \\
\text { dependent } \\
\text { variable }\end{array}$ & $\begin{array}{c}\text { (6) } \\
\text { Only most reliable } \\
\text { data on } \\
\text { willingness to } \\
\text { emigrate }\end{array}$ \\
\hline $\begin{array}{l}\text { Stock } \\
\text { migrants/population in } \\
2000\end{array}$ & $\begin{array}{c}0.72 * * * \\
(0.29)\end{array}$ & $\begin{array}{c}0.69 * * * \\
(0.28)\end{array}$ & $\begin{array}{c}0.71 * * \\
(0.32)\end{array}$ & $\begin{array}{c}0.95 * * * \\
(0.24)\end{array}$ & $\begin{array}{c}0.62 * * * \\
(0.14)\end{array}$ & $\begin{array}{c}0.73 * * * \\
(0.22)\end{array}$ \\
\hline $\begin{array}{l}\text { Stock people with } \\
\text { family } \\
\text { abroad/population }\end{array}$ & $\begin{array}{c}0.86^{* *} \\
(0.41)\end{array}$ & $\begin{array}{c}0.83 * * \\
(0.41)\end{array}$ & $\begin{array}{l}1.20^{*} \\
(0.63)\end{array}$ & $\begin{array}{c}1.70 * * * \\
(0.30)\end{array}$ & $\begin{array}{c}1.50 * * * \\
(0.26)\end{array}$ & $\begin{array}{c}2.87 * * * \\
(0.47)\end{array}$ \\
\hline $\begin{array}{l}\text { Real GDP per person } \\
(1,000 \text { \$ PPP), } \\
\text { destination in } 2000\end{array}$ & $\begin{array}{c}0.014 * * * \\
(0.003)\end{array}$ & $\begin{array}{l}0.02 * * * \\
(0.003)\end{array}$ & $\begin{array}{l}0.02 * * * \\
(0.003)\end{array}$ & $\begin{array}{l}0.03 * * * \\
(0.002)\end{array}$ & $\begin{array}{c}0.03 * * * \\
(0.002)\end{array}$ & $\begin{array}{l}0.03 * * * \\
(0.003)\end{array}$ \\
\hline $\begin{array}{l}\text { Empl/Pop 15+, } \\
\text { destination in } 2000\end{array}$ & $\begin{array}{c}0.001 \\
(0.001)\end{array}$ & $\begin{array}{c}0.005^{* * * *} \\
(0.001)\end{array}$ & $\begin{array}{c}0.005^{* * *} \\
(0.001)\end{array}$ & $\begin{array}{c}0.002 \\
(0.003)\end{array}$ & $\begin{array}{c}0.008 * * \\
(0.004)\end{array}$ & $\begin{array}{l}0.009 * \\
(0.005)\end{array}$ \\
\hline $\begin{array}{l}\text { Growth of GDP per } \\
\text { person } 2000-2010\end{array}$ & $\begin{array}{c}-0.002 * * \\
(0.001)\end{array}$ & $\begin{array}{c}-0.001 \\
(0.001)\end{array}$ & $\begin{array}{l}-0.0007 \\
(0.0007)\end{array}$ & $\begin{array}{c}-0.002 * \\
(0.001)\end{array}$ & $\begin{array}{l}-0.001 \\
(0.001)\end{array}$ & $\begin{array}{c}-0.001 \\
(0.001)\end{array}$ \\
\hline Standard controls & $\begin{array}{c}\text { Origin } \mathrm{FE}, \\
\ln \left(\mathrm{Pop}_{\mathrm{d}}\right)\end{array}$ & $\begin{array}{l}\text { Origin FE, } \\
\ln \left(\mathrm{Pop}_{\mathrm{d}}\right)\end{array}$ & $\begin{array}{l}\text { Origin FE, } \\
\ln \left(\mathrm{Pop}_{\mathrm{d}}\right)\end{array}$ & $\begin{array}{l}\text { Origin FE, } \\
\ln \left(\mathrm{Pop}_{\mathrm{d}}\right)\end{array}$ & $\begin{array}{l}\text { Origin FE, } \\
\ln \left(\mathrm{Pop}_{\mathrm{d}}\right)\end{array}$ & $\begin{array}{l}\text { Origin FE, } \\
\ln \left(\mathrm{Pop}_{\mathrm{d}}\right)\end{array}$ \\
\hline $\begin{array}{l}\text { Geographical and } \\
\text { cultural controls }\end{array}$ & $\begin{array}{l}\ln (\text { distance }), \\
\text { border, common } \\
\text { lang. }\end{array}$ & $\begin{array}{l}\text { ln(distance), } \\
\text { border, common } \\
\text { lang. }\end{array}$ & $\begin{array}{l}\ln (\text { distance }), \\
\text { border, common } \\
\text { lang. }\end{array}$ & $\begin{array}{l}\text { ln(distance), } \\
\text { border, common } \\
\text { lang. }\end{array}$ & $\begin{array}{l}\text { ln(distance), } \\
\text { border, common } \\
\text { lang. }\end{array}$ & $\begin{array}{l}\text { ln(distance), } \\
\text { border, common } \\
\text { lang. }\end{array}$ \\
\hline
\end{tabular}

Notes: The specification estimated corresponds to column (5) in Tables 3 and 4. Columns (1)-(3) refer to non-college educated, columns (4)-(6) refer to college educated. In columns 1 and 4 we include also destination-continent dummies. In columns 2 and 5 we use only the measure of people willing to emigrate relative to the population in 2000 as dependent. In columns 3 and 6 we select those bilateral observations on willingness to migrate that included at least 75 or 37 surveyed people, respectively. The observations are weighted by the country of origin population with college education, and we drop migration rates smaller than 0 and larger than the $99^{\text {th }}$ percentile of the distribution. Standard errors are clustered by country of origin. $* * *, * *, *$ imply significance at $1 \%, 5 \%$ and $10 \%$ level. 
Table 7: Determinants of net migration rates $(\mathrm{m} \times 100)$ of the less educated

138 sending countries to our 30 destination countries, 2000-2010

\begin{tabular}{|c|c|c|c|c|c|c|}
\hline Explanatory Variable: & $\begin{array}{c}(1) \\
\text { Basic }\end{array}$ & $\begin{array}{l}\text { (2) } \\
\text { Control for } \\
\text { levels }\end{array}$ & $\begin{array}{c}\text { (3) } \\
\text { Include } \\
\text { network }\end{array}$ & $\begin{array}{c}\text { (4) } \\
\text { Add Free labor } \\
\text { mobility } 2000 \\
\text { and visa waiver }\end{array}$ & $\begin{array}{c}\text { (5) } \\
\text { Free labor, } \\
\text { geography and } \\
\text { culture }\end{array}$ & $\begin{array}{c}\text { (6) } \\
\text { As (4) using } \\
\text { desire to migrate } \\
\text { permanently }\end{array}$ \\
\hline $\begin{array}{l}\text { Potential Emigration } \\
\text { rates, Low Skilled }\end{array}$ & $\begin{array}{c}0.046 * * * \\
(0.009)\end{array}$ & $\begin{array}{c}0.046 * * * \\
(0.009)\end{array}$ & $\begin{array}{l}0.038 * * * \\
(0.0009)\end{array}$ & $\begin{array}{c}0.046 * * * \\
(0.009)\end{array}$ & $\begin{array}{c}0.047 * * * \\
(0.0102)\end{array}$ & $\begin{array}{c}0.058 * * \\
(0.012)\end{array}$ \\
\hline $\begin{array}{l}\text { GDP growth, destination } \\
2000-2010\end{array}$ & $\begin{array}{l}0.0002^{*} \\
(0.0001)\end{array}$ & $\begin{array}{l}0.0002^{*} \\
(0.0001)\end{array}$ & $\begin{array}{l}0.0002 * \\
(0.0001)\end{array}$ & $\begin{array}{l}0.0003^{* *} \\
(0.0001)\end{array}$ & $\begin{array}{l}0.0002 * * \\
(0.0001)\end{array}$ & $\begin{array}{l}0.0002 * * \\
(0.0001)\end{array}$ \\
\hline $\begin{array}{l}\text { (Empl/Pop 15+) growth, } \\
\text { destination 2000-2010 }\end{array}$ & $\begin{array}{c}0.0005 \\
(0.0003)\end{array}$ & $\begin{array}{c}0.0005 \\
(0.0003)\end{array}$ & $\begin{array}{c}0.0005 \\
(0.0003)\end{array}$ & $\begin{array}{c}0.0004 \\
(0.0003)\end{array}$ & $\begin{array}{l}0.0006^{*} \\
(0.0003)\end{array}$ & $\begin{array}{c}0.006 \\
(0.005)\end{array}$ \\
\hline $\begin{array}{l}\text { Stock people with family } \\
\text { abroad/population }\end{array}$ & & & $\begin{array}{l}0.036 * * \\
(0.017)\end{array}$ & & & \\
\hline $\begin{array}{l}\text { Free labor movement } \\
\text { dummy }\end{array}$ & & & & $\begin{array}{l}0.0106 * * \\
(0.0051)\end{array}$ & $\begin{array}{l}-0.0114^{*} \\
(0.0060)\end{array}$ & $\begin{array}{l}0.012 * * \\
(0.004)\end{array}$ \\
\hline Visa waiver dummy & & & & $\begin{array}{l}0.0108 * * \\
(0.0047)\end{array}$ & $\begin{array}{l}0.0076^{*} \\
(0.0042)\end{array}$ & $\begin{array}{c}0.006 \\
(0.005)\end{array}$ \\
\hline $\begin{array}{l}\text { Real GDP per person } \\
(1,000 \$ \text { PPP), } \\
\text { destination in } 2000\end{array}$ & & $\begin{array}{l}-0.00004 \\
(0.00007)\end{array}$ & & & & \\
\hline $\begin{array}{l}\text { Employment/Population } \\
\text { working age destination } \\
\text { in } 2000\end{array}$ & & $\begin{array}{l}-0.0002 \\
(0.0002)\end{array}$ & & & & \\
\hline Standard controls & Origin FE & Origin FE & Origin FE & Origin FE & Origin FE & Origin FE \\
\hline $\begin{array}{l}\text { Geographical and } \\
\text { cultural controls }\end{array}$ & None & None & None & None & $\begin{array}{l}\text { ln(distance), } \\
\text { border, common } \\
\text { lang., colony, } \\
\text { legal origin, } \\
\text { currency, } \\
\text { landlocked, } \\
\text { religious prox., } \\
\text { genetic distance }\end{array}$ & None \\
\hline
\end{tabular}

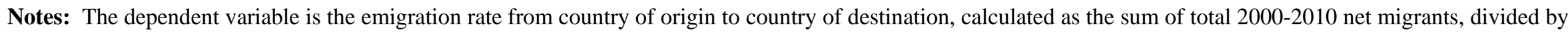

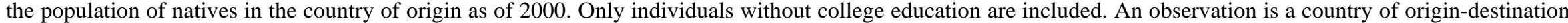

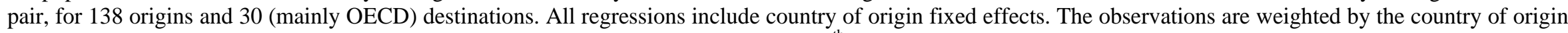

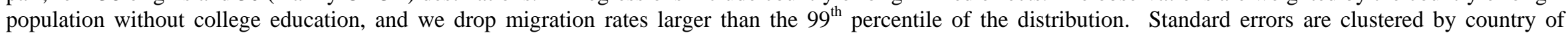
origin,.***,**,* imply significance at $1 \%, 5 \%$ and $10 \%$ level. 
Table 8: Determinants of net migration rates $(\mathrm{m} \times 100)$ of college educated

All sending countries to our 30 destination countries, 2000-2010

\begin{tabular}{|c|c|c|c|c|c|c|}
\hline Explanatory Variable: & $\begin{array}{c}(1) \\
\text { Basic }\end{array}$ & $\begin{array}{c}(2) \\
\text { Control for } \\
\text { levels }\end{array}$ & $\begin{array}{c}\text { (3) } \\
\text { Include } \\
\text { network }\end{array}$ & $\begin{array}{c}(4) \\
\text { Add Free labor } \\
\text { mobility } 2000 \\
\text { and visa waiver }\end{array}$ & $\begin{array}{c}\text { (5) } \\
\text { Free labor, } \\
\text { geography and } \\
\text { culture } \\
\end{array}$ & $\begin{array}{c}\text { (6) } \\
\text { As (4) using } \\
\text { desire to migrate } \\
\text { permanently } \\
\end{array}$ \\
\hline $\begin{array}{l}\text { Potential Emigration } \\
\text { rates, High Skilled }\end{array}$ & $\begin{array}{c}0.13^{* * *} \\
(0.03)\end{array}$ & $\begin{array}{c}0.13^{* * *} \\
(0.03)\end{array}$ & $\begin{array}{c}0.12^{* * *} \\
(0.03)\end{array}$ & $\begin{array}{c}0.13^{* * *} \\
(0.02)\end{array}$ & $\begin{array}{c}0.13^{* * *} \\
(0.03)\end{array}$ & $\begin{array}{c}0.17 * * * \\
(0.03)\end{array}$ \\
\hline $\begin{array}{l}\text { GDP growth, destination } \\
2000-2010\end{array}$ & $\begin{array}{c}0.0008^{* * *} \\
(0.0003)\end{array}$ & $\begin{array}{c}0.0009 * * * \\
(0.0003)\end{array}$ & $\begin{array}{c}0.0008^{* * *} \\
(0.0003)\end{array}$ & $\begin{array}{c}0.0006 \\
(0.0004)\end{array}$ & $\begin{array}{c}0.0006 \\
(0.0003)\end{array}$ & $\begin{array}{c}0.0002 \\
(0.0003) \\
\end{array}$ \\
\hline $\begin{array}{l}\text { (Empl/Pop 15+) growth, } \\
\text { destination 2000-2010 }\end{array}$ & $\begin{array}{l}-0.002^{*} \\
(0.001)\end{array}$ & $\begin{array}{l}-0.003 * * \\
(0.0015) \\
\end{array}$ & $\begin{array}{l}-0.002 \\
(0.001) \\
\end{array}$ & $\begin{array}{l}-0.0023^{*} \\
(0.0013) \\
\end{array}$ & $\begin{array}{c}-0.0024^{*} \\
(0.001) \\
\end{array}$ & $\begin{array}{c}-0.0027^{* *} \\
(0.0012) \\
\end{array}$ \\
\hline $\begin{array}{l}\text { Stock people with family } \\
\text { abroad/population }\end{array}$ & & & $\begin{array}{c}0.06 \\
(0.11)\end{array}$ & & & \\
\hline $\begin{array}{l}\text { Free labor movement } \\
\text { dummy }\end{array}$ & & & & $\begin{array}{c}0.0056 \\
(0.0145) \\
\end{array}$ & $\begin{array}{c}0.0235 \\
(0.0216) \\
\end{array}$ & $\begin{array}{l}0.002 \\
(0.01)\end{array}$ \\
\hline Visa waiver dummy & & & & $\begin{array}{l}-0.0338 \\
(0.0208)\end{array}$ & $\begin{array}{l}-0.0351 \\
(0.0236)\end{array}$ & $\begin{array}{c}-0.04 \\
(0.024)\end{array}$ \\
\hline $\begin{array}{l}\text { Real GDP per person } \\
(1,000 \text { \$ PPP), } \\
\text { destination in } 2000\end{array}$ & & $\begin{array}{c}0.0001 \\
(0.0002)\end{array}$ & & & & \\
\hline $\begin{array}{l}\text { Employment/Population } \\
\text { working age destination } \\
\text { in } 2000\end{array}$ & & $\begin{array}{l}-0.0006 \\
(0.0006)\end{array}$ & & & & \\
\hline Standard controls & Origin FE & Origin FE & Origin FE & Origin FE & Origin FE & Origin FE \\
\hline $\begin{array}{l}\text { Geographical and } \\
\text { cultural controls }\end{array}$ & None & None & None & None & $\begin{array}{l}\text { ln(distance), } \\
\text { border, common } \\
\text { lang., colony, } \\
\text { legal origin, } \\
\text { currency, } \\
\text { landlocked, } \\
\text { religious prox., } \\
\text { genetic distance }\end{array}$ & None \\
\hline
\end{tabular}

Notes: The dependent variable is the emigration rate from country of origin to country of destination, calculated as the sum of total 2000 -2010 net migrants, divided by the population of natives in the country of origin as of 2000. Only individuals with college education are included. An observation is a country of origin-destination pair, for 138 origins and 30 (mainly OECD) destinations. All regressions include country of origin fixed effects. The observations are weighted by the country of origin population with college education, and we drop migration rates larger than the $99^{\text {th }}$ percentile of the distribution. Standard errors are clustered by country of origin..***,**,* imply significance at $1 \%, 5 \%$ and $10 \%$ level. 
Table 9: Same matching function for college educated and the less educated

Change in immigration flows and rates in the destination countries

\begin{tabular}{|c|c|c|c|c|c|c|c|}
\hline & \multicolumn{3}{|c|}{$\begin{array}{l}\text { Net inflow 2000-2010 } \\
\text { Less educated }\end{array}$} & \multicolumn{2}{|c|}{$\begin{array}{l}\text { Net immigration rate 2000-2010 } \\
\text { Less educated }\end{array}$} & \multicolumn{2}{|c|}{$\begin{array}{l}\text { Net immigration rate } 2000-2010 \\
\text { Total }\end{array}$} \\
\hline & Observed & Counterfactual & Change & Observed & Counterfactual & Observed & Counterfactual \\
\hline Australia & $-43,572$ & 156,502 & 200,074 & -0.6 & 2.2 & 6.5 & 8.7 \\
\hline Austria & 131,191 & 245,474 & 114,283 & 3.1 & 5.7 & 4.0 & 6.4 \\
\hline Belgium & 98,126 & 190,134 & 92,008 & 2.0 & 4.0 & 4.4 & 5.8 \\
\hline Canada & $-106,830$ & 203,246 & 310,076 & -0.8 & 1.6 & 11.9 & 13.9 \\
\hline Chile & $1,134,916$ & $1,208,874$ & 73,958 & 16.7 & 17.8 & 17.5 & 18.4 \\
\hline Denmark & 84,565 & 117,438 & 32,873 & 2.9 & 4.0 & 3.9 & 4.8 \\
\hline Finland & 71,786 & 97,746 & 25,960 & 2.4 & 3.3 & 2.8 & 3.6 \\
\hline France & 531,354 & $1,423,387$ & 892,033 & 1.8 & 4.7 & 2.7 & 5.2 \\
\hline Germany & 343,256 & 878,725 & 535,469 & 0.8 & 2.0 & 0.8 & 1.7 \\
\hline Greece & 437,392 & 532,983 & 95,591 & 7.1 & 8.6 & 9.5 & 10.8 \\
\hline Ireland & 97,686 & 178,475 & 80,789 & 6.1 & 11.2 & 11.7 & 15.6 \\
\hline Israel & $-205,390$ & $-200,132$ & 5,258 & -18.7 & -18.2 & -10.6 & -10.3 \\
\hline Italy & 474,837 & $1,164,453$ & 689,616 & 1.3 & 3.1 & 1.9 & 3.5 \\
\hline Japan & 139,541 & 618,870 & 479,329 & 0.2 & 1.0 & 0.4 & 0.9 \\
\hline Luxembourg & 18,538 & 26,751 & 8,213 & 10.5 & 15.2 & 12.3 & 16.4 \\
\hline Mexico & 49,710 & 145,167 & 95,457 & 0.1 & 0.4 & 0.3 & 0.5 \\
\hline Netherlands & $-310,625$ & $-168,669$ & 141,956 & -4.3 & -2.3 & -3.5 & -2.0 \\
\hline New Zealand & 100,327 & 213,531 & 113,204 & 9.1 & 19.4 & 8.9 & 14.9 \\
\hline Norway & 114,426 & 210,155 & 95,729 & 5.2 & 9.6 & 7.3 & 10.6 \\
\hline Poland & $-189,459$ & $-187,202$ & 2,257 & -0.9 & -0.9 & -0.7 & -0.7 \\
\hline Portugal & 424,044 & 540,023 & 115,979 & 6.7 & 8.6 & 8.2 & 9.8 \\
\hline Russian Federation & $-1,117,531$ & $-1,049,495$ & 68,036 & -2.7 & -2.6 & -0.7 & -0.6 \\
\hline Saudi Arabia & 997,625 & $2,294,148$ & $1,296,523$ & 20.4 & 46.8 & 31.1 & 54.8 \\
\hline South Africa & 505,528 & 740,170 & 234,642 & 2.8 & 4.1 & 4.2 & 5.3 \\
\hline Spain & $2,328,310$ & $3,588,335$ & $1,260,025$ & 10.6 & 16.3 & 12.3 & 17.0 \\
\hline Sweden & 198,125 & 307,922 & 109,797 & 4.7 & 7.3 & 7.1 & 9.1 \\
\hline Switzerland & 94,586 & 292,052 & 197,466 & 3.0 & 9.1 & 3.1 & 8.1 \\
\hline United Arab Emirates & $1,269,853$ & $1,700,601$ & 430,748 & 248.4 & 332.6 & 303.9 & 374.3 \\
\hline United Kingdom & 275,684 & $1,457,422$ & $1,181,738$ & 0.9 & 4.6 & 4.1 & 7.3 \\
\hline United States & $4,629,616$ & $10,387,622$ & $5,758,006$ & 6.3 & 14.0 & 5.0 & 8.6 \\
\hline Total/Average & $12,577,615$ & $27,314,708$ & $14,737,093$ & 17.0 & 36.9 & 16.1 & 25.3 \\
\hline
\end{tabular}


Table 10: Effects of interactions opportunity-potential on migration rates $(\mathbf{m} \times 100)$

All sending countries to our 30 destination countries, 2000-2010

\begin{tabular}{|c|c|c|c|c|c|c|}
\hline \multirow[b]{2}{*}{ Explanatory Variable: } & \multicolumn{3}{|c|}{ Less educated } & \multicolumn{3}{|c|}{ College educated } \\
\hline & $\begin{array}{c}\text { (1) } \\
\text { Potential- } \\
\text { growth }\end{array}$ & $\begin{array}{c}(2) \\
\text { Potential- } \\
\text { policy }\end{array}$ & $\begin{array}{c}\text { (3) } \\
\text { Potential- } \\
\text { network }\end{array}$ & $\begin{array}{c}\text { (4) } \\
\text { Potential- } \\
\text { growth }\end{array}$ & $\begin{array}{c}\text { (5) } \\
\text { Potential- } \\
\text { policy }\end{array}$ & $\begin{array}{c}(6) \\
\text { Potential- } \\
\text { network }\end{array}$ \\
\hline Potential Emigration rates & $\begin{array}{l}0.04 * * * \\
(0.015)\end{array}$ & $\begin{array}{l}0.0464 * * \\
(0.0229)\end{array}$ & $\begin{array}{c}0.039 * * * \\
(0.011)\end{array}$ & $\begin{array}{c}0.13^{* * * *} \\
(0.03)\end{array}$ & $\begin{array}{c}0.3080 * * * \\
(0.1115)\end{array}$ & $\begin{array}{c}0.12 * * * \\
(0.03)\end{array}$ \\
\hline $\begin{array}{l}\text { GDP growth, destination } \\
2000-2010\end{array}$ & $\begin{array}{c}0.00018 \\
(0.00013)\end{array}$ & $\begin{array}{l}0.0003 * * \\
(0.0001)\end{array}$ & $\begin{array}{c}0.0002 \\
(0.0001)\end{array}$ & $\begin{array}{c}0.0008 * * * \\
(0.0002)\end{array}$ & $\begin{array}{l}0.0008 * \\
(0.0004)\end{array}$ & $\begin{array}{c}0.008 * * * \\
(0.003)\end{array}$ \\
\hline $\begin{array}{l}\text { (Empl/Pop 15+) growth, } \\
\text { destination 2000-2010 }\end{array}$ & $\begin{array}{l}0.001^{* * *} \\
(0.0004)\end{array}$ & $\begin{array}{c}0.0004 \\
(0.0003)\end{array}$ & $\begin{array}{c}0.0004 \\
(0.0003)\end{array}$ & $\begin{array}{c}-0.004^{* * *} \\
(0.001)\end{array}$ & $\begin{array}{l}-0.0022 * \\
(0.0012)\end{array}$ & $\begin{array}{l}-0.002 \\
(0.001)\end{array}$ \\
\hline $\begin{array}{l}\text { Stock people with family } \\
\text { abroad/population }\end{array}$ & & & $\begin{array}{c}0.015 \\
(0.051)\end{array}$ & & & $\begin{array}{c}0.08 \\
(0.07)\end{array}$ \\
\hline $\begin{array}{l}\text { Free labor movement } \\
\text { dummy }\end{array}$ & & $\begin{array}{c}0.0038 \\
(0.0061)\end{array}$ & & & $\begin{array}{l}-0.0348 \\
(0.0372)\end{array}$ & \\
\hline Visa waiver dummy & & $\begin{array}{l}0.0110 * * \\
(0.0045)\end{array}$ & & & $\begin{array}{l}-0.0019 \\
(0.0233)\end{array}$ & \\
\hline $\begin{array}{l}\text { Interaction } \\
\text { (Potential) x (GDP growth) }\end{array}$ & $\begin{array}{l}0.027 * * \\
(0.013)\end{array}$ & & & $\begin{array}{c}0.017 \\
(0.016)\end{array}$ & & \\
\hline $\begin{array}{l}\text { Interaction } \\
\text { (Potential) x (free) }\end{array}$ & & $\begin{array}{c}0.0145 \\
(0.0151)\end{array}$ & & & $\begin{array}{c}0.0597 \\
(0.0447)\end{array}$ & \\
\hline $\begin{array}{l}\text { Interaction } \\
\text { (Potential) x (visa waiver) }\end{array}$ & & $\begin{array}{l}-0.0003 \\
(0.0078)\end{array}$ & & & $\begin{array}{l}-0.0716^{*} \\
(0.0404)\end{array}$ & \\
\hline $\begin{array}{l}\text { Interaction } \\
\text { (Potential) x (network) }\end{array}$ & & & $\begin{array}{c}0.004 \\
(0.013)\end{array}$ & & & $\begin{array}{l}-0.01 \\
(0.07)\end{array}$ \\
\hline Controls & Origin FE & Origin FE & Origin FE & Origin FE & Origin FE & Origin FE \\
\hline
\end{tabular}

Notes: The dependent variable is the emigration rate from country of origin to country of destination, calculated as the sum of total 2000-2010 net migrants, divided by the population of natives in the country of origin as of 2000. Only individuals without college education are included in regressions 13 , while only individual with college education are included in 4-6. An observation is a country of origin-destination pair, for 138 origins and 30 (mainly OECD) destinations. All regressions include country of origin fixed effects. The observations are weighted by the country of origin population in the relevant education group, and we drop migration rates larger than the $99^{\text {th }}$ percentile of the distribution. Standard errors are clustered by country of origin. $* * *, * *, *$ imply significance at $1 \%, 5 \%$ and $10 \%$ level. 
Table 11: Do poor sending countries have a different effect on migration rates? $(\mathrm{m} \times \mathbf{1 0 0})$

Sending countries in Asia, Latin America and Asia to our 30 destination countries, 2000-2010

\begin{tabular}{|c|c|c|c|c|c|c|}
\hline \multirow[b]{2}{*}{ Explanatory Variable: } & \multicolumn{3}{|c|}{ Less educated } & \multicolumn{3}{|c|}{ College educated } \\
\hline & $\begin{array}{c}\text { (1) } \\
\text { Basic with geo } \\
\text { controls }\end{array}$ & $\begin{array}{c}\text { (2) } \\
\text { Control for } \\
\text { income } \\
\text { levels }\end{array}$ & $\begin{array}{c}\text { (3) } \\
\text { With } \\
\text { potential- } \\
\text { growth } \\
\text { interaction }\end{array}$ & $\begin{array}{c}(4) \\
\text { Basic with geo } \\
\text { controls }\end{array}$ & $\begin{array}{c}\text { (5) } \\
\text { Control for } \\
\text { income levels }\end{array}$ & $\begin{array}{c}\text { (6) } \\
\text { With } \\
\text { potential- } \\
\text { growth } \\
\text { interaction }\end{array}$ \\
\hline Potential Emigration rates & $\begin{array}{c}0.06 * * * \\
(0.01)\end{array}$ & $\begin{array}{c}0.05 * * * \\
(0.01)\end{array}$ & $\begin{array}{c}0.04 * * \\
(0.02)\end{array}$ & $\begin{array}{c}0.18 * * * \\
(0.03)\end{array}$ & $\begin{array}{c}0.22 * * * \\
(0.04)\end{array}$ & $\begin{array}{c}0.17 * * * \\
(0.03)\end{array}$ \\
\hline $\begin{array}{l}\text { GDP growth, destination } \\
\text { 2000-2010 }\end{array}$ & $\begin{array}{c}0.0006 * * * \\
(0.0002)\end{array}$ & $\begin{array}{l}0.0002^{*} \\
(0.0001)\end{array}$ & $\begin{array}{c}0.0002 \\
(0.0001)\end{array}$ & $\begin{array}{l}0.0016 * * \\
(0.0007)\end{array}$ & $\begin{array}{c}0.0015 * * * \\
(0.0005)\end{array}$ & $\begin{array}{l}0.0008^{* *} \\
(0.0004)\end{array}$ \\
\hline $\begin{array}{l}\text { (Empl/Pop 15+) growth, } \\
\text { destination 2000-2010 }\end{array}$ & $\begin{array}{l}0.001 * * \\
(0.0005)\end{array}$ & $\begin{array}{c}0.0005 \\
(0.0003) \\
\end{array}$ & $\begin{array}{c}0.001 * \\
(0.0005)\end{array}$ & $\begin{array}{c}-0.006 * * \\
(0.002)\end{array}$ & $\begin{array}{c}-0.004^{* *} \\
(0.001)\end{array}$ & $\begin{array}{c}-0.006 * * \\
(0.002)\end{array}$ \\
\hline $\begin{array}{l}\text { Real GDP per person }(1,000 \\
\$ \text { PPP), destination in } 2000\end{array}$ & & $\begin{array}{l}-0.00002 \\
(0.00008) \\
\end{array}$ & & & $\begin{array}{c}0.0009 \\
(0.0005) \\
\end{array}$ & \\
\hline $\begin{array}{l}\text { Empl/Pop } 15+\text {, destination in } \\
2000\end{array}$ & & $\begin{array}{l}0.00007 \\
(0.0001) \\
\end{array}$ & & & $\begin{array}{l}-0.001 \\
(0.001)\end{array}$ & \\
\hline Visa Waiver Dummy & & $\begin{array}{l}0.014^{*} \\
(0.007)\end{array}$ & & & $\begin{array}{c}-0.059 * * \\
(0.024) \\
\end{array}$ & \\
\hline $\begin{array}{l}\text { Interaction } \\
\text { (Potential) x (GDP growth) }\end{array}$ & & & $\begin{array}{l}0.03 * * \\
(0.014)\end{array}$ & & & $\begin{array}{c}0.03 \\
(0.03)\end{array}$ \\
\hline Standard controls & Origin FE & Origin FE & Origin FE & Origin FE & Origin FE & Origin FE \\
\hline $\begin{array}{l}\text { Geographical and cultural } \\
\text { controls }\end{array}$ & $\begin{array}{l}\text { ln(distance), } \\
\text { border, common } \\
\text { lang., colony, } \\
\text { legal origin, } \\
\text { currency, } \\
\text { landlocked, } \\
\text { religious prox., } \\
\text { genetic distance } \\
\end{array}$ & None & None & $\begin{array}{l}\text { ln(distance), } \\
\text { border, common } \\
\text { lang., colony, } \\
\text { legal origin, } \\
\text { currency, } \\
\text { landlocked, } \\
\text { religious prox., } \\
\text { genetic distance }\end{array}$ & None & None \\
\hline
\end{tabular}

Notes: The dependent variable is the emigration rate from country of origin to country of destination, calculated as the sum of total 2000-2010 net migrants, divided by the population of natives in the country of origin as of 2000. Only individuals without college education are included in regressions $1-$ 3, while only individual with college education are included in 4-6. An observation is a country of origin-destination pair, for Asian, African and Latina American countries of origin and 30 (mainly OECD) destinations. All regressions include country of origin fixed effects. The observations are weighted by the country of origin population in the relevant education group, and we drop migration rates larger than the $99^{\text {th }}$ percentile of the distribution. Standard errors are clustered by country of origin. ***,**,* imply significance at $1 \%, 5 \%$ and $10 \%$ level. 


\section{$\underline{\text { Appendix Tables and Fiqures }}$}

Table A1. Summary statistics for explanatory variables and controls

\begin{tabular}{|c|c|c|c|c|c|}
\hline & Observations & Mean & Standard dev. & Min & Max \\
\hline Real GDP per person, in 2000 PPP \$, destination & 5363 & 27606.65 & 11633.00 & 5893.64 & 62626.35 \\
\hline Real GDP per person, in 2000 PPP \$, origin & 5363 & 10392.59 & 12829.56 & 117.22 & 74162.94 \\
\hline (Empl/Pop 15 years and older)x100, destination & 5115 & 53.72 & 7.32 & 38.70 & 74.40 \\
\hline (Empl/Pop 15 years and older)x100, origin & 5115 & 57.43 & 11.03 & 35.40 & 85.50 \\
\hline Distance in KM & 5456 & 7353.83 & 4437.13 & 114.63 & 19539.47 \\
\hline Border Dummy & 5456 & 0.02 & 0.14 & 0.00 & 1.00 \\
\hline Dummy for common language & 5456 & 0.12 & 0.33 & 0.00 & 1.00 \\
\hline Dummy for shared colonial past & 5456 & 0.03 & 0.18 & 0.00 & 1.00 \\
\hline Dummy for common legal origin & 5456 & 0.25 & 0.43 & 0.00 & 1.00 \\
\hline Dummy for common currency & 5456 & 0.02 & 0.15 & 0.00 & 1.00 \\
\hline Sum of landlocked dummies & 5394 & 0.35 & 0.53 & 0.00 & 2.00 \\
\hline Measure of Religious proximity & 5673 & 0.26 & 0.25 & 0.00 & 0.98 \\
\hline Genetic distance (Spolaore and Wacziarg 2010) & 5672 & 912.53 & 647.90 & 0.00 & 3115.87 \\
\hline
\end{tabular}


Table A2

Correlation between potential and actual migrants: aggregate regressions across countries of origin

\begin{tabular}{|c|c|c|c|c|}
\hline \multirow[b]{2}{*}{ Explanatory Variable: } & \multicolumn{2}{|c|}{ College Educated } & \multicolumn{2}{|c|}{ Non College Educated } \\
\hline & $\begin{array}{c}(1) \\
\text { Basic }\end{array}$ & $\begin{array}{c}\text { (2) } \\
\text { Including controls }\end{array}$ & $\begin{array}{c}\text { (3) } \\
\text { Basic }\end{array}$ & $\begin{array}{c}\text { (4) } \\
\text { Including controls }\end{array}$ \\
\hline Potential Emigration rates & $\begin{array}{c}0.45 * * * \\
(0.09)\end{array}$ & $\begin{array}{r}0.18^{*} \\
(0.11)\end{array}$ & $\begin{array}{c}0.054 * * \\
(0.023)\end{array}$ & $\begin{array}{c}0.031 \\
(0.026)\end{array}$ \\
\hline $\begin{array}{l}\text { Stock of people with household } \\
\text { members abroad/population }\end{array}$ & & $\begin{array}{c}1.31 * * * \\
(0.29) \\
\end{array}$ & & $\begin{array}{c}0.16 \\
(0.10) \\
\end{array}$ \\
\hline $\begin{array}{l}\text { Real GDP per person in origin }(1,000 \\
\$ \text { PPP) }\end{array}$ & & $\begin{array}{c}-0.0009 * * \\
(0.0004)\end{array}$ & & $\begin{array}{c}-0.0001 \\
(0.00008)\end{array}$ \\
\hline
\end{tabular}

Notes: The dependent variable is the emigration rate from country of origin, calculated as the sum of total 2000 -2010 net migrants, divided by the population of natives in the country of origin as of 2000. Each observation is one of 138 countries of origin. The observations are weighted by the country of origin population with college education, and we drop migration rates. Standard errors are heteroskedasticity-robust.***,**,* imply significance at $1 \%$, $5 \%$ and $10 \%$ level. 
Table A3: Actual and desired immigration rates of college educated and the less educated by origin country

\begin{tabular}{|c|c|c|c|c|c|}
\hline Destination & $\begin{array}{l}\text { Net rates } 2000-2010 \\
\text { Less educated }\end{array}$ & $\begin{array}{l}\text { Net rates } 2000-2010 \\
\text { College educated }\end{array}$ & $\begin{array}{l}\text { Desired rates } \\
\text { Less educated }\end{array}$ & $\begin{array}{c}\text { Desired rates } \\
\text { College educated }\end{array}$ & $\begin{array}{c}\text { Population } \\
\text { Ratio of College } \\
\text { educated } \\
\text { to Less educated }\end{array}$ \\
\hline Afghanistan & 0.378 & 6.177 & 10.992 & 19.133 & 0.080 \\
\hline Albania & 9.800 & 66.976 & 31.793 & 37.139 & 0.077 \\
\hline Algeria & 0.869 & 14.494 & 14.581 & 11.298 & 0.057 \\
\hline Argentina & 1.011 & 5.362 & 10.009 & 16.731 & 0.129 \\
\hline Armenia & 1.068 & 23.480 & 22.542 & 27.471 & 0.250 \\
\hline Australia & 0.354 & 4.507 & 9.368 & 13.170 & 0.264 \\
\hline Austria & -1.683 & -1.435 & 7.172 & 13.164 & 0.129 \\
\hline Azerbaijan & -2.652 & 9.143 & 9.429 & 11.751 & 0.128 \\
\hline Bahrain & 0.273 & 25.890 & 1.624 & 1.286 & 0.039 \\
\hline Bangladesh & 0.625 & 9.568 & 19.274 & 39.107 & 0.043 \\
\hline Belarus & -4.283 & 3.939 & 10.854 & 19.675 & 0.267 \\
\hline Belgium & 0.563 & 2.863 & 10.592 & 14.828 & 0.313 \\
\hline Belize & 2.682 & 112.886 & 20.548 & 23.120 & 0.082 \\
\hline Bolivia & 3.819 & 12.268 & 12.754 & 16.509 & 0.161 \\
\hline Bosnia and Herzegovina & -8.676 & 30.384 & 8.992 & 12.029 & 0.074 \\
\hline Botswana & 1.911 & 18.839 & 13.689 & 26.923 & 0.041 \\
\hline Brazil & 0.266 & 2.692 & 11.186 & 16.786 & 0.078 \\
\hline Bulgaria & 2.344 & 9.667 & 9.399 & 17.075 & 0.222 \\
\hline Burundi & 0.259 & 55.932 & 6.835 & 100.000 & 0.006 \\
\hline Cambodia & 0.692 & 93.310 & 22.932 & 35.913 & 0.006 \\
\hline Cameroon & 0.535 & 50.278 & 23.027 & 26.316 & 0.012 \\
\hline Canada & -0.110 & 4.879 & 10.531 & 14.435 & 0.215 \\
\hline Chad & 0.086 & 6.766 & 7.625 & 9.536 & 0.013 \\
\hline Chile & 0.564 & 2.641 & 15.608 & 22.114 & 0.265 \\
\hline China & 0.058 & 2.132 & 3.986 & 16.260 & 0.044 \\
\hline Colombia & 1.259 & 11.135 & 25.792 & 27.996 & 0.118 \\
\hline Comoros & 4.424 & 62.206 & 23.615 & 27.083 & 0.014 \\
\hline Congo, Dem. Rep. & 0.200 & 17.908 & 21.740 & 32.340 & 0.013 \\
\hline Costa Rica & 0.981 & 4.720 & 14.774 & 12.217 & 0.198 \\
\hline Cote d'Ivoire & 1.183 & 5.692 & 18.648 & 31.635 & 0.114 \\
\hline Croatia & -13.400 & 15.867 & 5.505 & 3.586 & 0.049 \\
\hline Cyprus & 1.019 & 16.455 & 8.017 & 20.576 & 0.308 \\
\hline Czech Republic & 0.223 & 3.481 & 6.125 & 10.748 & 0.112 \\
\hline Denmark & 0.044 & 5.510 & 10.245 & 17.892 & 0.202 \\
\hline
\end{tabular}


Djibouti

Dominican Republic

Ecuador

Egypt

El Salvador

Estonia

Finland

France

Georgia

Germany

Ghana

Greece

Guatemala

Guinea

Haiti

Honduras

Hong Kong

Hungary

Iceland

India

Indonesia

Iran

Iraq

Ireland

Israel

Italy

Japan

Jordan

Kazakhstan

Kenya

Korea, Rep.

Kuwait

Kyrgyz Republic

Laos

Latvia

Lebanon

Liberia

Libya

Lithuania

Luxembourg

0.163
5.648
5.656
0.757
16.468
9.479
-0.912
0.391
-4.758
0.247
0.391
-3.072
6.856
0.733
3.262
8.275
0.048
-0.238
3.630
0.202
0.034
0.001
0.745
2.048
0.977
-1.128
-0.032
5.707
-2.768
0.241
0.220
4.772
2.167
0.989
-0.148
2.567
0.566
-0.031
-0.416
1.973

9.730

28.502

18.771

17.673

52.111

34.634

4.077

3.402

4.129

1.977

21.397

2.909

56.715

16.814

413.808

64.760

31.626

4.948

26.855

6.138

2.520

6.424

11.618

25.211

6.125

4.189

0.113

26.634

18.240

34.199

4.794

365.757

18.820

39.954

13.470

106.875

72.704

20.362

10.454

10.770
15.035

47.102

17.558

8.988

30.475

16.532

12.253

10.026

13.510

17.467

38.529

8.294

21.976

25.030

30.746

27.495

12.892

13.174

17.259

2.151

2.714

15.280

5.714

11.822

11.773

11.418

9.924

15.854

9.080

22.248

17.631

3.155

11.721

5.569

15.229

17.914

36.635

14.197

14.590

14.294

$\begin{array}{cc}25.041 & 0.023 \\ 41.319 & 0.141 \\ 21.474 & 0.173 \\ 11.011 & 0.046 \\ 43.006 & 0.102 \\ 15.811 & 0.374 \\ 17.788 & 0.158 \\ 21.906 & 0.207 \\ 17.428 & 0.128 \\ 19.090 & 0.244 \\ 38.106 & 0.044 \\ 18.251 & 0.177 \\ 25.288 & 0.036 \\ 40.866 & 0.022 \\ 46.658 & 0.009 \\ 32.201 & 0.041 \\ 26.892 & 0.163 \\ 12.595 & 0.143 \\ 20.385 & 0.183 \\ 10.789 & 0.051 \\ 8.042 & 0.028 \\ 34.391 & 0.100 \\ 10.998 & 0.099 \\ 18.579 & 0.298 \\ 19.336 & 0.622 \\ 29.441 & 0.103 \\ 16.476 & 0.400 \\ 21.073 & 0.168 \\ 10.397 & 0.147 \\ 34.018 & 0.023 \\ 29.832 & 0.367 \\ 3.810 & 0.015 \\ 17.599 & 0.181 \\ 5.214 & 0.043 \\ 17.260 & 0.153 \\ 20.382 & 0.051 \\ 50.322 & 0.025 \\ 13.045 & 0.024 \\ 19.149 & 0.184 \\ 23.526 & 0.159\end{array}$


Macedonia

Malawi

Malaysia

Mali

Malta

Mauritania

Mexico

Moldova

Mongolia

Morocco

Namibia

Nepal

Netherlands

New Zealand

Nicaragua

Niger

Nigeria

Norway

Pakistan

Palestinian Territory

Panama

Paraguay

Peru

Philippines

Poland

Portugal

Qatar

Romania

Russian Federation

Saudi Arabia

Senegal

Serbia and Montenegro

Sierra Leone

Singapore

Slovakia

Slovenia

Somalia

South Africa

Spain

Sri Lanka

\begin{tabular}{cc}
-1.651 & 2.225 \\
0.574 & 58.055 \\
0.072 & 7.300 \\
0.793 & 30.780 \\
-0.073 & 82.980 \\
0.912 & 24.469 \\
8.082 & 13.677 \\
0.284 & 19.020 \\
-0.253 & 2.819 \\
2.845 & 30.630 \\
4.218 & 147.195 \\
0.130 & 7.705 \\
0.366 & 5.904 \\
1.208 & 10.634 \\
3.130 & 20.994 \\
0.022 & 4.017 \\
0.086 & 13.993 \\
0.102 & 2.834 \\
1.263 & 12.676 \\
24.910 & 462.255 \\
0.120 & -0.456 \\
2.539 & 14.275 \\
2.066 & 6.774 \\
1.263 & 8.927 \\
0.555 & 8.927 \\
0.459 & 14.386 \\
0.344 & 7.166 \\
3.559 & 21.593 \\
0.105 & 0.196 \\
0.102 & 2.845 \\
1.451 & 42.790 \\
6.023 & 10.734 \\
0.604 & 159.058 \\
0.242 & 17.872 \\
-3.928 & 5.773 \\
-2.241 & 0.424 \\
2.013 & 68.930 \\
0.141 & 6.880 \\
-0.622 & 1.020 \\
0.265 & 6.927 \\
& \\
\hline
\end{tabular}

$\begin{array}{ccc}20.411 & 23.354 & 0.077 \\ 25.671 & 22.212 & 0.005 \\ 3.694 & 13.611 & 0.094 \\ 12.955 & 33.952 & 0.007 \\ 15.248 & 32.181 & 0.066 \\ 14.241 & 18.200 & 0.017 \\ 14.990 & 21.899 & 0.134 \\ 23.324 & 26.176 & 0.101 \\ 11.524 & 24.488 & 0.138 \\ 13.345 & 14.496 & 0.080 \\ 9.838 & 0.000 & 0.023 \\ 9.658 & 30.391 & 0.038 \\ 13.125 & 17.603 & 0.292 \\ 18.953 & 18.219 & 0.740 \\ 21.204 & 29.015 & 0.143 \\ 4.457 & 24.315 & 0.008 \\ 38.182 & 45.891 & 0.022 \\ 10.681 & 18.430 & 0.304 \\ 7.844 & 19.147 & 0.076 \\ 8.352 & 14.915 & 0.039 \\ 12.473 & 18.372 & 0.261 \\ 5.643 & 16.226 & 0.074 \\ 27.216 & 26.472 & 0.266 \\ 17.689 & 36.457 & 0.338 \\ 8.761 & 10.529 & 0.143 \\ 8.222 & 18.336 & 0.108 \\ 3.943 & 3.664 & 0.130 \\ 17.650 & 25.497 & 0.100 \\ 6.168 & 12.775 & 1.146 \\ 1.677 & 1.138 & 0.119 \\ 31.836 & 50.986 & 0.024 \\ 15.799 & 14.764 & 0.150 \\ 36.755 & 58.638 & 0.008 \\ 5.143 & 9.596 & 0.088 \\ 13.226 & 22.771 & 0.131 \\ 11.271 & 13.831 & 0.192 \\ 21.398 & 24.950 & 0.015 \\ 8.557 & 12.060 & 0.094 \\ 6.926 & 15.131 & 0.223 \\ 9.796 & 17.767 & \end{array}$




\begin{tabular}{|c|c|c|c|c|c|}
\hline Sudan & 0.476 & 42.557 & 15.457 & 30.189 & 0.010 \\
\hline Sweden & 0.590 & 3.088 & 14.710 & 14.997 & 0.286 \\
\hline Switzerland & 0.501 & 5.725 & 8.036 & 3.627 & 0.221 \\
\hline Syria & 1.235 & 21.870 & 16.570 & 20.079 & 0.048 \\
\hline Taiwan & 0.054 & 4.110 & 11.572 & 21.201 & 0.255 \\
\hline Tajikistan & 0.768 & 24.293 & 10.230 & 15.363 & 0.074 \\
\hline Tanzania & 0.055 & 23.923 & 14.821 & 48.836 & 0.009 \\
\hline Thailand & 0.237 & 3.912 & 3.024 & 4.772 & 0.057 \\
\hline Trinidad and Tobago & 3.520 & 280.268 & 14.799 & 21.332 & 0.036 \\
\hline Tunisia & 0.041 & 12.257 & 15.095 & 21.749 & 0.058 \\
\hline Turkey & -1.532 & 4.039 & 8.785 & 14.523 & 0.100 \\
\hline Turkmenistan & -0.213 & 4.151 & 5.913 & 13.173 & 0.182 \\
\hline Ukraine & -3.318 & 2.398 & 11.449 & 17.524 & 0.611 \\
\hline United Arab Emirates & 5.127 & 13.111 & 1.047 & 3.816 & 0.196 \\
\hline United Kingdom & 0.500 & 13.984 & 21.765 & 27.524 & 0.147 \\
\hline United States & 0.202 & 0.322 & 8.223 & 11.708 & 1.149 \\
\hline Uruguay & 2.447 & 12.497 & 9.220 & 10.507 & 0.122 \\
\hline Uzbekistan & 0.817 & 11.082 & 6.428 & 8.857 & 0.125 \\
\hline Venezuela & 0.536 & 4.595 & 6.729 & 12.209 & 0.170 \\
\hline Vietnam & 0.673 & 32.555 & 7.173 & 15.427 & 0.024 \\
\hline Yemen & 1.514 & 103.992 & 16.277 & 29.681 & 0.012 \\
\hline Zambia & 0.477 & 37.382 & 15.698 & 22.855 & 0.021 \\
\hline Zimbabwe & 2.255 & 203.604 & 24.296 & 33.774 & 0.010 \\
\hline Average & 1.149 & 33.341 & 14.221 & 21.437 & 0.145 \\
\hline
\end{tabular}

Note: The net migration rate is constructed as described in the text, namely as net emigration 2000-2010 divided by the population of natives in the country of origin as of 2000, and then multiplying this fraction by 100 . Countries with negative rates have a net inflow of their nationals (return), countries with net rates larger than $100 \%$ (only for college educated) may have some of their expatriates obtain a degree abroad. 